Benito Arruñada

\title{
Mandatory Accounting Disclosure by Small Private Companies*
}

\begin{abstract}
Computerised databases and the Internet have recently made publication of company accounts potentially less costly and more useful, thanks to electronic filing and universal online access to credit information systems. These developments advise against simplification policies that would reduce the scope of mandatory publication. Instead, they encourage policies pursuing a broader efficiency goal, achievable by reducing costs and enhancing value through administrative reforms of filing, archive and retrieval systems. Survey and registry evidence on how the information in the accounts is valued and used by firms fully supports these claims.
\end{abstract}

Keywords: financial disclosure, company accounts, credit registries, business simplification JEL classification: G32, K22, M48

\footnotetext{
${ }^{*}$ Department of Economics and Business. Pompeu Fabra University. Trias Fargas, 25. 08005-Barcelona (Spain). E-mail: benito.arrunada@upf.edu. I thank Mariano Álvarez Pérez, Michael Buneman, Belén de la Casa, Salvador Carmona, Luis Fernández del Pozo, Uriel González-Montes, Andreas Kalenteridis, Gema Pérez and Celestino Suárez Viñuela. Usual disclaimers apply. This study received financial support from the Spanish Ministry of Education and Science, through grant SEJ2005-03871/ECON and the European Commission through the Integrated Project CIT3-513420.
} 


\section{Introduction}

There are substantial differences in the regulation in different countries on financial disclosure by private companies and, in particular, on publication of their accounts. In the USA, Japan and some other countries, most private companies, whatever their size, are not obliged to disclose financial information. In contrast, in the European Union all companies are required to file their accounts with a public register. Most other countries also require many of their private companies to publicly file their accounts (UNCTAD, 2005: 92).

Discussions of these disclosure and publication requirements have led to disparate recommendations to slightly expand publication requirements (as in the UK [CLRSG, 2000; DTI, 2005]), maintain them (as in Hong Kong [SCCLR, 2000] and Malaysia [CLRC, 2007]) and reduce them (as in Australia [PJSCCS, 2001], Singapore [CLRFC, 2002]). More recently, as part of its initiative to simplify the business environment and lessen administrative burdens, the European Commission (2007) has also proposed to exempt small companies so that they would not necessarily be required by national law to publish their accounts. ${ }^{1}$

The Commission grounds its proposal on the argument that for such companies publishing the accounts causes considerable cost with no significant benefit. On the one hand, according to the Commission, the requirement constitutes a major administrative burden. On the other, it is

${ }^{1}$ In particular, the European Commission (2007) has proposed to define a category of small companies or "micro entities" that would be exempt from the accounting directives. This category of potentially exempted firms would cover corporate entities with less than 10 employees, less than $0.5 \mathrm{~m} €$ in assets and less than $1 \mathrm{~m} €$ in turnover. In addition, the Commission suggested relieving from publication requirements all "small" companies - that is, those meeting at least two of the following three criteria: less than 50 employees, less than $4.4 \mathrm{~m} €$ in assets and less than $8.8 \mathrm{~m} €$ in turnover. The Commission also proposed treating medium-sized companies without a "particular external user" as small companies. A company would be considered medium-sized if it meets at least two of the following three criteria: less than 250 employees, assets lower than $17.5 \mathrm{~m} €$ and turnover lower than $35 \mathrm{~m} €$. The number of companies potentially exempted would be between 88 and 97\% in different EU countries, according to the European Committee of Central Balance Sheet Data Offices (ECCBSO, 2007: 3). 
inconsequential if — when given freedom to disclose or not—small firms choose not to disclose because their accounts are only "used by a limited number of stakeholders, such as credit institutions and suppliers that have the possibility to require financial information directly from the company" (European Commission, 2007: 17).

Mandatory publication of accounts by private companies relates to several strands of the economic, accounting and financial literatures: deregulation of business formalities, mandatory financial disclosure, and investors' protection and credit information. Findings in all these areas thus provide complementary insights on the issue under discussion.

The European Commission aims to improve the environment of businesses by simplifying business formalities, a popular policy since the European Charter for Small Enterprises (2000) and the efforts of the World Bank through the "Doing Business" project (2003-2007). This origin of the initiative helps explain the focus of the Commission on reducing costs without considering benefits. As we will see, however, mandatory publication of accounts is not only an issue of reducing the costs of operating businesses but also of easing businesses' access to credit. The discussion therefore fits in with the argument given by Arruñada $(2007,2008)$ that simplification policies that narrowly focus on reducing the cost of institutional arrangements are counterproductive when they disregard the value of the services being provided (compare, however, Djankov et al., 2002, and Djankov, 2008).

Furthermore, in the case at hand, other strands of the accounting and finance literatures provide complementary perspectives for understanding the complex sets of costs and benefits involved. Since the 1960s, there has been substantial controversy on the balance of costs and benefits and the optimal content of mandatory financial disclosure. In the current regulatory framework of the USA, ${ }^{2}$ however, most of these discussions have focused on mandatory

2 In the USA, Japan and some other countries most private companies, whatever their size, are not obliged to disclose financial information. However, "in most countries, many or even all entities are required by national law or regulation to prepare financial statements that conform to a required set of generally accepted accounting principles, and for these financial statements to be audited in accordance with a required set of generally accepted auditing standards. These audited financial statements are normally filed with a government agency and thus are available to creditors, suppliers, employees, governments, and others.” (UNCTAD, 2005: 92). 
disclosure by public companies — that is, companies selling shares or bonds to individual investors in stock exchanges. These public companies are required by law to not only file financial information publicly on a periodic basis but also to disclose other information on the company, provide detailed data on new issues of securities and report any trade by insiders.

Even though the European Commission's proposal refers to the mandatory publication of annual accounts by small private companies, part of the discussion on mandatory disclosure by public companies is applicable. Other parts of the analysis are substantially different, however, because of differences in the governance structure, size and availability of information of both types of companies, as well as differences in the contents of the information being mandatorily disclosed. In particular, previous research has focused on how mandatory disclosure for public companies affects the value of their equity by facilitating or not transactions on such equity. But the main interest for private companies lies in knowing how publishing their accounts could help their trading parties (mainly banks and suppliers) estimate their credit risk, thus expanding their access to credit and lowering its cost. The main effect should be to reduce information asymmetry in credit (including trade credit) transactions instead of in equity transactions.

In addition, given that the shares of public companies are traded in the stock market, it is possible to estimate the impact of mandatory disclosure on the value of the public companies. However, even if the reduction in the transaction costs of credit caused by mandatory publication of accounts also increases firm value, we cannot measure this effect because we lack market prices for equity shares in private companies. Therefore, without a comprehensive metric for evaluating the impact of mandatory publication of accounts, we can only aspire to building an enlightened qualitative inventory of costs and benefits. This difference, however, might be less substantial than it seems, as important disagreements remain amongst those measuring the effects of mandatory disclosure for public companies, ${ }^{3}$ to the extent that opinions on mandatory disclosure end up being a matter of qualitative judgement. ${ }^{4}$

\footnotetext{
${ }^{3}$ After more than four decades of empirical studies following the pioneer study by Stigler (1964), evidence on the effects of mandatory disclosure is mixed. The main studies that avoid confounding the effect of introducing the mandatory disclosure rule with unobserved shocks experienced by all companies' shares are the following. Chow (1983) finds a negative effect on value in a small sample of
} 
Finally, mandatory financial disclosure may play a key role in economic growth, as it is an important element of the legal system intended to "protect” firms' transactions with investors and creditors. Protecting such transactions plays a crucial role in the development of modern financial markets, ${ }^{5}$ and financial development is an important factor of economic growth. ${ }^{6}$ Most studies focus on public companies trading in the stock market but similar claims can be made about private companies, mainly considering the evidence on the cost of credit. ${ }^{7}$ The volume of credit contracted in an economy depends on two factors: information available on debtors' quality, ${ }^{8}$ and the rights that the legal system grants to creditors in case of default. ${ }^{9}$ For the availability of information, the factor on which we are most interested, empirical evidence shows that the volume of credit grows when banks share more information on debtors and when the quality of credit registries improves. ${ }^{10}$ It seems that the better the creditors know the quality and record of potential debtors, the lower the transaction costs of credit, probably because of both improved debtors' incentives and easier avoidance of adverse selection. As we will see, the main

companies after the 1933 Securities Act. Simon (1989) observes a significant decrease in risk (as measured by the dispersion of abnormal returns) for new issues after the 1933 Act. Bushee and Leuz (2005) find many smaller firms delisting and value increases for firms previously disclosing and those which started disclosing after disclosure requirements were extended in 1999 to small companies trading in the over-the-counter market. Greenstone, Oyer and Vissing-Jorgensen (2006) find a substantial increase in value for companies affected by the 1964 Amendments that extended disclosure requirements to large firms trading over-the-counter.

4 For opposing views on empirical evidence and policy, see Easterbrook and Fischel (1984), (Coffee, 1984), Romano (1998), Choi (2000), Healy, Paul and Palepu (2001), and Zingales (2004).

5 So-called "investor protection"-in fact, transaction protection, as rational investors cease transacting when foreseeing they will not be paid back - has been claimed to facilitate dispersed share ownership, large equity markets and entrepreneurs' access to capital (La Porta, Lopez de Silanes and Shleifer, 1999; La Porta, Lopez de Silanes, Shleifer and Vishny, 1997, 2002).

${ }^{6}$ Rajan and Zinagales (1998), and Castor, Clementi and MacDonald (2004).

${ }^{7}$ Hansmann, Kraakman and Squire also conjecture that creditor protection-including mandatory publication of financial statements by private companies - may be a precondition for contractual freedom among investors (2005: 5). Whatever the overall merits of their argument, its application to mandatory publication of financial statements is flawed to the extent that publication was introduced in continental Europe long after such flexible forms were developed (the relevant EU directives date from 1968 and 1978) and even most German companies do not comply with the rule (Weilbach, 1991).

8 Mainly Jaffee and Russell (1976) and Stiglitz and Weiss (1981).

${ }^{9}$ Mainly Townsend (1979), Aghion and Bolton (1992), and Hart and Moore (1994, 1998). 
reason for the publication of accounts is that it allows improved assessment of credit risk for both individual transactions and bank and macroeconomic regulation.

This article analyses the publication of company accounts and argues that information technologies are reducing its costs and increasing its benefits, providing greater justification for mandatory publication of accounts. In addition to throwing light on the policy discussion on the regulation of accounting disclosure by private companies, this article offers three main contributions. First, it demonstrates that deregulation policies that focus too narrowly on reducing the cost of regulation may be counterproductive because they disregard the value of the services being provided by such regulation. Second, it complements the literature on mandatory financial disclosure by focusing on private companies, whereas previous studies have mainly focused on public companies. Third, it confirms that the main benefit of disclosure by private companies is that it facilitates credit transactions. Finally, the article provides empirical evidence supporting such beneficial effects on credit transactions.

The rest of the paper proceeds as follows. Section 2 analyses the costs of having private companies make their accounts public, distinguishing direct administrative costs, possible distortions in competition and the erosion of privacy. It concludes that account publication is not prohibitively costly and that administrative costs can and should be reduced further. Some other costs, such as damage to competition and privacy are doubtful, especially for micro and small companies. Section 3 maps the appropriable benefits of having private companies making their accounts public. It focuses on why publication improves on asking for and delivering accounts for individual transactions, and shows that most demand for company accounts is for those of small companies. Section 4 examines the externalities of account publication, paying special attention to those in credit assessment and bank regulation. It shows the essential function that published company accounts now play in the functioning of credit information systems; the role of these systems in reducing the cost of credit; and the damage that would be caused by a reduction in account publication, as it would not only reduce coverage but also the accuracy of all credit risk assessments. Section 5 discusses the reasons why a rule of voluntary publication

10 Jappelli and Pagano (2002), Sapienza (2002), and Djankov, McLiesh and Shleifer (2007). 
would not be efficient. Firms do not have enough incentives to publish as they do not appropriate all the benefits, due to information asymmetries, externalities that would not be overcome by private arrangements, and the survival of inefficient social norms on privacy. On the contrary, it seems relatively easy for governments to structure commercial registers in such a way as to achieve a more efficient trade-off of costs and benefits. Moreover, account publication heavily influences cross-border trade through its impact on the cost of credit, a good reason for establishing the rule at the European Union level. Section 6 concludes.

\section{Mapping costs}

Publishing company accounts involves substantial private costs. These include the direct administrative cost of preparing and filing the accounts. There may be other less direct costs, as publication may cause a competitive disadvantage for the disclosing firms, which may damage their incentives to invest. A third type of private cost is the loss of personal privacy.

\subsection{Administrative costs}

These costs are not trivial, as revealed by the lack of compliance observed when enforcement is lenient, as in Germany (Weilbach, 1991: 800) or The Netherlands (Bolle, 1996). It has been argued that to avoid the costs of mandatory publication some firms are willing to do substantial restructuring (Barry, 2006), and publication avoidance has played a role in some massive changes in organisational form (Maijoor, 1996). Furthermore, mandatory disclosure may also interfere in the optimal choice of safeguarding instruments (Gore, Sachs and Trzcinka, 2004).

The size of these costs is open to question, however, at least for most firms. First, the direct cost of compliance is small. The cost of producing the annual accounts is close to nil as the accounts are a standard by-product of any accounting software, which is in any case indispensable for managerial and tax accounting. Informal consultation with providers of tax, administrative and advisory services suggests that their prices would not be noticeably affected 
by ceasing to file small clients' accounts. Furthermore, the cost of filing the accounts can and should be minimised by extending the use of new technologies (electronic filing ${ }^{11}$ ) and eliminating useless procedures (such as notarising the signature of the company representative, which is still required in Spain). In general, given that company accounts are not subject to any substantive review by the register, it is relatively easy to automate the process. ${ }^{12}$

Publishing financial accounts also incurs additional costs for administering and regulating the disclosure, as well as for filing and processing the information. To the extent that these services are financed by the filing firms, most of these costs are the same as those analysed in the previous paragraph. However, examining their structure is worthwhile because it suggests that even a substantial drop in account publication might reduce costs very little for two reasons. First, investments by public registries, to make account filing possible and to manage the information flow, and by private firms, to capture and exploit the information, are mostly sunk costs and therefore irrelevant in the short run. Second, because both filing and exploiting the files offer substantial economies of scale. Therefore, many costs would be incurred anyway to serve the non-exempted firms and those which voluntarily decide to continue filing their accounts.

Lastly, part of the cost savings obtained by not filing the accounts would disappear, as all firms would be repeatedly required to provide more specific information to different agents. Such demanders of information would not only be their several banks and suppliers (this demand could be satisfied by voluntarily disclosing), but also public agencies which would stop relying on the public record of accounts (if this became substantially less complete) and would start building additional databases as well as enlarging their current demand of information from

11 Use of the "extensible business reporting language" (XBRL) filing format, now permitted, for instance, by the USA's Securities and Exchange Commission, holds the promise of further cost reductions (see, e.g., Hannon and Gold, 2005).

12 The limited formal control that the register can perform may even be counterproductive. For example, some registers consistently check that the figures in the accounts add up, and reject them if otherwise. However, unbalanced accounts are probably more informative to users when they are trying to ascertain any unreliability in the filing firm. 
firms. ${ }^{13}$ Of course, national governments could avoid this new demand for information by implementing mandatory disclosure. However, as explained in section 5.3, the strength of entrenched local private interests makes it unlikely that political bodies at the national level would enact a rule of mandatory disclosure even if such a rule were efficient.

\subsection{Distortion of competition}

Publication of accounts might also cause private costs to the disclosing firm by informing its competitors, which might also distort competition. However, this effect seems unlikely to be substantial when small companies are involved. ${ }^{14}$ At least, these costs are clearly smaller than those of the disclosure now commonly required from public companies. A useful comparison would be that between the impact of publicly filing the annual accounts with that of announcing, for instance, the cancellation of a research programme. Doubt remains on this point, however, not for the micro and small companies considered by the European Commission but for mediumsized or even large private companies, for which disclosure may be quite sensitive, given their size and presence in concentrated and differentiated markets.

The lesser competitive effects for smaller firms are confirmed by the results of a survey conducted in October 2007 among Spanish users of a business information system, the results of which are shown in Table 1 (question 5). ${ }^{15}$ The percentage of firms which use the service to find

13 "It is highly probable that SMEs would have to face more individual questions from public authorities, bankers and other stakeholders and consequently several requirements and formats will replace the former ones and therefore they will incur additional costs” (ECCBSO, 2007: 4).

14 For a similar reason, the lack of separation of ownership and control in private companies avoids another source of costs: suboptimal decisions by managers. For public companies, surveys find that most managers of public companies are willing to sacrifice long-term value to smooth earnings (Grahan, Harvey and Rajgopal, 2005). See, however, Arya, Glover and Sunder (2003), who argue that managed earnings may be good for shareholders.

15 The survey was conducted by a major provider of online credit information for small firms in a large EU country. It was conducted online on October 25-26, 2007 by sending 74,862 emails to a random sample of registered users, offering each of them a free credit report (market price 13.92 €) if they 
out about competitors, given by the third answer, decreases significantly with the size of the user firm, as suggested by the differences in average use between groups of firms of different size (Table 1). This is confirmed by the positive coefficient obtained for the Firm Size variable in the econometric estimation in which the dependent variable is Competitors, a binary variable equal to one when the firm uses the service to gain information on competitors, zero otherwise (model [1] in Table 3).

Nor does the fact that outlets in vertically integrated networks would be subject to different reporting requirements seem to create a significant cost difference. Franchised outlets publish their accounts when they are incorporated as companies, while vertically integrated outlets do not need to do so when they are mere divisions of the franchising firm. ${ }^{16}$ The potential difference in disclosure costs seems a trifle when considering that different rules apply to both types of vertical structures in matters such as resale price maintenance, collective bargaining or corporate tax rates.

\subsection{Privacy cost}

Damage to privacy, considered as a highly significant cost by some authors (e.g., Barry, 2006), is elusive and difficult to evaluate. The fact that most positive law does not grant privacy rights to corporations could be interpreted as an implicit social judgement whereby, overall, such privacy costs are not social costs. Two reasons may help in explaining why. First, a substantial part of the demand for company privacy is directed at tax evasion and fraud and therefore has little merit from a social perspective. Second, and closer to our case, it is doubtful that companies should be held to a lower standard of publicity than individuals. For individuals, most modern legal systems now protect privacy on financial matters but require publicity of the most

answered the survey. A total of 5,924 users filled in the survey in 24 hours, with a response rate of 7.91\%. Most of the respondents were small firms (Table 2).

16 The difference has been pointed out by Barry (2006: 20). Arruñada, Vázquez and Zanarone (2008) make use of public information to observe substantial differences in performance between these vertical structures. 
important assets and liabilities: property rights on real estate, valuable movable goods, such as automobiles, and even some financial assets, as with holdings in public companies. Notice that publicity on real property often refers not only to ownership rights but also to mortgages. ${ }^{17}$ The consequence is that the most valuable assets in the "balance sheets" of individuals are made public. In this context, exempting legal persons from publicity would allow them to hide property by means of legal entities incorporated for the sole purpose of holding property, a practice that is already widespread for hiding cross-border real estate purchases from the tax authorities.

\section{Mapping appropriable benefits}

Publication of company accounts also provides benefits to the companies involved, to their trading partners and to third parties. This section examines those which are appropriable by the disclosing company.

\subsection{Benefits for disclosers and their partners}

Benefits for disclosing companies and their trading partners arise from reducing the information asymmetry between them: publishing the accounts grants access to potential and current trading partners to the historical record, current financial position and profitability of the disclosing firm. This reduction in information asymmetry is especially valuable in transactions that embody future obligations for the firm: clients purchasing durable goods, all parties investing in firm-specific assets, minority shareholders and, especially, trade and financial

17 The contents of the land registers are wholly open to the public in 28 of the 42 jurisdictions reported in UN-ECE (2000). 
creditors. Understandably, more transparent firms have been found to incur lower costs of debt and equity capital. ${ }^{18}$

Furthermore, publishing the accounts may be more credible and less costly than communicating them individually to contractual parties or handing them only to those parties who request them explicitly. Credibility is gained because filing the accounts with an independent third party (the register) commits the firm, as accounts already filed cannot be modified and future accounts will have to be consistent with those filed in the past. Costs are reduced because it is no longer necessary to deliver them to a high number of trade creditors, and prospective creditors or third parties will no longer have to ask for the accounts to be delivered to them. Let us examine this second aspect in some depth.

\subsection{Individual disclosure as an alternative to public disclosure}

The alternative solution proposed by the European Commission is for the creditor to ask for the borrowers' financial statements. This solution is problematic, not least because there are often more than two parties to the transaction.

Information provided to a party in a one-to-one interaction is often less credible than that provided to all potential parties by filing it in a public registry. Some evidence on this is given by the common practice in banking of, as a first step, checking loan applications (which often include specifically adapted financial statements) against reports prepared by business

18 As modelled, among many others, by Diamond and Verrecchia (1991) and shown empirically, e.g., by Francis, Khurana and Pereira (2005), using firm-level data, and Bhattacharya, Daouk and Welker (2003), using country-level data, as well as Hail (2002) and Nikolaev and Van Lent (2005). Good quality in financial reporting has been associated with lower price declines in financial crises, according to Mitton (2002), in the 1997-1998 Asian crisis, and to Barton and Waymire (2004), in the 1920s. See, however, Leftwich (2004). It has also been observed that companies enjoy lower cost of credit after selling shares for the first time to the public, with the disclosure that this implies (Pagano, Panetta and Zingales, 1998). Similarly, bond yields are lower in USA states that have mandated GAAP disclosure, especially among organisations with relatively higher information asymmetry (Gore, 2004). 
information agencies. ${ }^{19}$ One may assume that if some credit applicants make up their accounts when dealing with banks, they are even more likely to do so when dealing with suppliers, given that suppliers are not experts in credit evaluation, do not have such ready access to additional information and are less likely to be a party in future transactions.

In addition, asking contractual parties for sensitive information is not always a sensible negotiating strategy, because it may destroy trust, which might be needed to adapt the transaction in the future. It may force the transaction to be more formal and legalistic. This seems especially important when making credit decisions as by-products of commercial transactions, many of which need future adaptation. On the other hand, explicit contracting for safeguards is relatively more common and accepted for credit than for commercial transactions, and fewer adaptations are needed.

Evidence on commercial practice supports the claim that asking parties directly is not sensible. Suppliers often obtain sensitive information from their banks and from other firms, instead of directly from their clients. They thus avoid offending the client and probably gain more reliable information. Prevalence of this practice is confirmed by the responses given in the survey to question 8 (Table 1): $47.16 \%$ of respondents rely on their banks and $41.83 \%$ on references from other firms to find out about the solvency of their clients and commercial partners (with $68.30 \%$ relying on banks or other firms and $21.07 \%$ on both).

Furthermore, the European Commission assumes that only two parties intervene in the credit transaction. However, as the previous example illustrates, it is often the case than there are more than two parties to the transaction, and the third party - the bank in the example-is not in a position to ask the prospective borrower for information. Instead, the bank will first check its own records if the prospective borrower is a bank client, and will always examine the external databases for information on the borrower's financial, judicial and tax status. If the buyer is not a bank client, the only independent information comes from such external databases. Asking the

\footnotetext{
${ }^{19}$ For information on this and other practices mentioned in different sections of the paper, see, on checking creditworthiness, http://www.payontime.co.uk/collect/collect creditworthy.html; about understanding credit rating, http://www.payontime.co.uk/collect/collect_understand_ratings.html; and about reducing risk, http://payontime.co.uk/collect/collect_riskreduce.html (visited October 5, 2007).
} 
borrower's bank is out of the question in a competitive banking environment because of the twin risks of being misled or losing the transaction.

A similar situation arises when a bank lends against receivables. In many cases, the bank will not be willing to discount notes receivable from a client without first evaluating the creditworthiness of the maker or drawee (often the bank client's client). If the drawee is not a client of the bank, the bank can hardly request this party's accounts, and the bank will decide based on the information available from external sources, mainly credit agencies. The availability of information allows the bank to identify that the drawee is a good risk and on this basis the bank lends to its own — by assumption, less solvent — client. (To benefit more directly from his creditworthiness, the good risk purchaser can enter into a "confirming" agreement with his banks by which the bank will pay suppliers before their debts are due).

Lastly, even more serious difficulties arise when contracting for factoring, invoice discounting or credit insurance agreements, because the factor or the insurer need information on multiple firms: usually all their client's customers. Both factoring and credit insurance are only producible on the basis of previous screening of borrowers, using databases compiled or produced by insurers who carefully examine both potential insured clients and borrowers.

\subsection{Small companies do benefit from publishing their accounts}

The European Commission is factually wrong when asserting in its Communication that there is little demand for the financial statements of micro entities and small companies. ${ }^{20}$

The Commission's mistake is easily proved by examining the actual demand for the accounts of micro and small companies filed in public registers. For primary demand, Table 4 in the Annex summarises the size distribution of companies whose accounts were requested by final

20 In particular, the Communication states that "there is a lack of broad demand" for accounts of microentities, (2007: 8) and that those of small companies "are used by a limited number of stakeholders, such as credit institutions and suppliers that have the possibility to require financial information from the company” (2007: 17). 
users at the Spanish Company Register: $95.43 \%$ of the total requests are for accounts of micro entities and small companies, the two main potentially exempted categories $(42.90 \%$ and $52.52 \%$, respectively). For secondary demand, Table 5 summarises the SABI database, commercialised by Bureau va Dijk, which purchases its data on Spanish companies from Informa D\&B S.A., which in turn purchases the raw data from the Spanish Company Register. Of all companies in this database, $96.05 \%$ are micro entities or small (48.81\% and 47.25\%, respectively). Moreover, the size distribution of companies in this database approximates reasonably well the size distribution of demand for three reasons. First, Informa and Bureau va Dijk are commercial operators, and are therefore unlikely to pay for and store useless data. Furthermore, over 2006-2007, final users requested information on 99.6\% of small private companies included in the databases of the three main credit information agencies operating in the Spanish market, according to its trade association (ASEDIE, 2007: 4). Lastly, the SABI database also approximates final demand because of the way in which credit information agencies have built up these databases over time. Every year, they purchase from the Register data on companies on which they have reported in previous years and process it. With every final user request for accounts not yet in the database, the agencies purchase such accounts but also update their annual demand for the future-therefore, they also update the composition of the database. In this case, after 15 years of updating, the database offers a picture of demand which is sufficiently accurate for our purposes. Certainly, information is requested by final users on some companies more than on others, but this bias is not only related to size but also to other factors, such as payment delays and insolvency. ${ }^{21}$

21 The demand for information on small companies can also be inferred from the massive nature of the demand for this type of information. In the first nine months of 2007, information on 1,933,220 different firms - as identified by their tax ID numbers - was requested at least once from one database in one EU country. Considering the size distribution of firms in the economy, it is clear that the bulk of this demand consists of information on micro and small firms. Such massive demand is also in line with the communication strategies that these agencies are following: e.g., an online provider specialising in small firms has recently run advertising campaigns at prime time on main national radio networks. 
In fact, it is likely that small firms benefit more from massive credit information systems based on mandatory disclosure than, at least, large and even medium-sized firms. ${ }^{22}$ This is because the size of large firms makes it sensible for financial analysts and even the press to spend resources monitoring them and reporting on them. Also, large firms deal with large numbers of contractual parties, and these act as powerful information networks. Small firms, by contrast, are unknown outside their own small circle. Credit information systems make it possible to use the reputational capital developed in this small circle when interacting with strangers. They therefore make possible the sort of anonymous trade that is often considered essential for economic growth. ${ }^{23}$

Our survey of users of the leading business information service in Spain is consistent with the claim that small firms benefit the most from the publication of accounts (Table 1, question 1). First, a vast majority of firms (88.77\%) use the system to know about micro and small companies, as defined by the European Commission. Only $11.23 \%$ use it for obtaining information on larger companies. Second, accounts are by far the most valuable piece of information they obtain (83.69\% of users valued them), followed afar by judicial incidents (54.95\%) and corporate information (31.35\%). Ready access to the accounts of small companies is therefore the key value added by this service.

The econometric analysis confirms these results. When regressing a binary variable representing a Large firms answer to the first question of the survey, which asks respondents if they usually consult the system to get information on large or small firms, the estimated coefficient for the Firm Size variable is significantly positive (model [2] in Table 3). This means that larger user firms are more likely to obtain information on large firms. Furthermore, a similar result obtains when firm size is measured in terms of the discreet categories proposed by the European Commission.

\footnotetext{
22 The additional difficulties suffered by a regime of voluntary disclosure for small firms, as analyzed below, make this consistent with the empirical correlation found between firm size and voluntary disclosure (e.g., Raffournier, 1995; Giner, 1997; Depoers, 2000).

23 See, for instance, North and Thomas (1973), Granovetter (1985), and Seabright (2004).
} 
The Commission's mistake in disdaining the demand for financial information and its value is understandable because the benefits of publishing the accounts have increased dramatically in recent years, thanks to recent changes in information technologies. First, the development of scanners and OCR (optical character recognition) software made it possible to introduce the accounts in computerised databases. More recently, the Internet has granted universal access to such databases at very low cost. The novelty of these changes makes it likely that many of the potential benefits have not yet been fully realised, as is the case with information technologies more generally. The rapid rate of growth of business information agencies, graphed in Figure 1, fully supports this conjecture.

The Commission's mistake might also be explainable by the focus of academic research on public companies. It is surely true that small firms would not benefit from the type of disclosure now required from public companies, which has been adapted to reduce information asymmetry in equity transactions (both in new sales of securities and between managers and shareholders in companies with dispersed ownership) and therefore requires more sophisticated and higherquality information. However, there is demand for lower quality information on small private companies. Two pieces of evidence support this claim. First, the market demands lower quality financial reporting from private than from public companies (Ball and Shivakumar, 2005). Second, when statistical methods are applied for assessing credit risk, the risk of smaller and private companies is estimated using statistical and discriminant methods, such as the one

pioneered by Altman (1968). However, the risk of public companies is more often estimated with structural and reduced-form models that rely on market prices of the debtor's securities, particularly the Merton 1974 model (De Servigny and Renault, 2004: 63-116). In short, information provided by filing small private companies' accounts is of low quality, but useful and in demand.

\section{Mapping externalities}

Every time a company publishes its accounts, it benefits third parties in ways that could hardly compensate the disclosing company in any practical way. Aggregated information on 
individual firms, even if very small, is valuable for credit information agencies, to improve the accuracy and predictive power of their credit rating models; for analysts and investors, as it allows them to do comparative analysis when allocating capital among firms and industries; for competitors and competitors' investors, when analysing the industry; for regulators and policymakers, when making decisions; for central banks, when evaluating the level of indebtness of the economy and the soundness of banks; and even for researchers doing empirical work.

One may expect that these effects would also indirectly benefit other economic agents, both at the micro and macroeconomic levels. This is the case, in particular, of credit information, bank regulation and national accounting.

\subsection{Externalities in credit information}

Financial information agencies produce reports containing all sorts of information that is of use for evaluating companies' creditworthiness. These reports, which may be customised depending on the needs of the client, often include several years of accounts as filed at the Company Register and the identity of the companies' shareholders and legal representatives. In addition, not only for companies but also for individual firms, reports might also include, if available, negative information about previous defaults, as filed by trade and financial creditors and courts, as well as contact information and news clips on the firm. As a summary, they may also offer a credit rating or even an estimated probability of default.

The accounts filed with the Company Register are a major component of credit reports, because of the problems plaguing alternative sources of information. Exclusive reliance on negative information about credit defaults worsens the quality of credit assessment, and financial institutions are often unwilling to share positive information on debtors (Powell et al., 2004). Furthermore, even sharing arrangements depend on the cooperation of established financial institutions, which poses serious risks to competition. ${ }^{24}$ Figure 1 plots the parallel evolution of

\footnotetext{
24 See, e.g., in the case of Spain, TDC (2005).
} 
account publication and the value of services provided by credit information agencies in Spain. The dramatic increase observed in the value of such services can hardly be explained by economic growth alone. Greater availability of a main input of credit reports-company accounts_-probably also played a major role.

\subsubsection{Information externalities}

The European Commission's proposal endangers the key services provided by these agencies. ${ }^{25}$ If a substantial number of companies were to stop publishing their accounts, this would not only reduce the coverage of services for such companies, but would also impoverish information at the industry level and, more important, would worsen the assessment of credit risk for all companies in the economy. Let us see why.

Obviously, reports on private companies that would stop filing their accounts would hardly contain any financial information. Their credit risk would therefore be badly estimated.

However, these effects would be trivial to the extent that they would be for the firm which would also be receiving the savings from not filing.

This full "internalisation" of damages would not occur in the two other effects, for which the non-publisher would still benefit from having other firms publishing the accounts. With less publication, all sorts of aggregate information about sectors of economic activity, as well as the firms in a state, region or town, would be less reliable. In addition, and worst of all, the ability to assess the credit risk of the firms that still publish their accounts would suffer because such assessment would be based on a smaller and possibly biased sample. Smaller, because some companies would not publish their accounts and biased, because the companies that decide not to publish them may share certain characteristics, making it more or less likely for them to publish.

\footnotetext{
25 See two descriptions of the services offered by two leading firms in Spain at http://www.informa.es/infornet/Main/idioma/01/idioma/01/screen/SShowPage/pagina/infoeconomica.htm

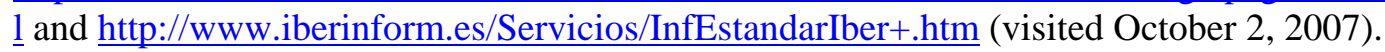


For instance, worse risks might be less inclined to publish. Firms not publishing their accounts would therefore be free riding on those publishing them.

In a context of costly publishing, this free riding opens the door to the possibility that fewer and fewer firms will continue publishing, and the information produced will become increasingly less valuable, triggering a sort of vicious circle. We can glimpse its effects from a similar and better-known case: reliance on negative information by credit bureaus. Even for a company filing its accounts, less comprehensive filing of accounts by other companies will probably bring similar consequences to those of constraining the use of positive information by credit bureaus specialising in consumer credit. With less information on file, the accuracy of their credit risk scoring models decreases. Consequently, credit becomes more costly and less available, banks face more difficulties for monitoring indebtedness and established creditors enjoy new barriers to entry, as shown by Barron and Staten (2003).

\subsubsection{Competition externalities}

Public availability of financial accounts improves the flow of credit-risk information, allowing suppliers and other potential creditors to evaluate credit risk by themselves without previous interaction with or personal knowledge of the potential debtor, and without resorting to intermediaries (mostly banks) who may hold such knowledge. It is understood that the more precise pricing of risk makes more transactions possible and improves the allocation of resources.

Furthermore, lesser asymmetry of information expands the type and number of potential lenders and risk bearers, which otherwise would be limited to the banks and suppliers which had contracted with the debtor firm in the past and developed personal knowledge about its creditworthiness. $^{26}$

26 This sort of "relationship banking” plays an important role in different models of the banking firm, from, e.g., Benston and Smith (1976) to Freixas and Rochet (1997). 
Such expansion takes place in several markets and dimensions, with substantial competitive effects. New transactions are made possible, including second party lending by suppliers—-trade credit without discounting, which amounts to disintermediating the banks—and third-party lending and risk partitioning. New participants can enter local, regional and national markets, from credit rating agencies to banks, factoring firms and credit insurers without branches in those markets. ${ }^{27}$ Many of these new participants are thus able to operate across borders, as foreign suppliers, lenders, informers and insurers can now rely more on objective, impersonal information. Within the financial industry, small banks become more capable of competing with large banks. Lastly, small firms in all markets are slightly more capable of competing with large firms, because they now have better access to the credit rating services which previously were less available to them than to large firms. The latter were anyway in a position to develop their own services for assessing credit risk.

Our survey of Spanish users of the main business information system is consistent with these claims (Table 1, questions 2, 7, 5 and 6), as they declare they use its services for granting credit to new clients (60.42\% of users) and closing sales that otherwise would not be carried out (45.97\%). Furthermore, more respondents use the information for new relationships of special significance (47.99\%) and all new relationships (37.02\%) than to monitor old relationships, whatever their importance. Its role in sales and credit decisions is also clear from the high proportion of users relying on it for getting information on clients (85.96\%) and for deciding about sales on credit (66.95\%). The resulting pattern of uses supports our claim that access to company accounts - the information that respondents value the most — expands trade opportunities and eases entry into new markets. Furthermore, econometric analysis finds that it is smaller firms that are most likely to use the information to grant credit to new clients (model [3] in Table 3).

27 Credit insurance relies heavily on credit information services, and the two activities are vertically integrated in many firms: the market leader on the Spanish market was created by a credit insurer (Informa, 2007), and the main French credit insurer acquired a credit information firm in 2004 to become the leader on the French market (Coface, 2007). 


\subsection{Externalities in banking regulation}

Financial institutions increasingly rely on external measures of credit risk to assess the value and riskiness of their loan portfolios, partly as a consequence of the Basel II guidelines which require a radical restructuring of how they assess credit risk, allowing them to use external credit assessments. ${ }^{28}$ Credit information systems are key for applying these Basel II approaches in that they help to analyse if credit provisioning is adequate, to assess capital requirements and to evaluate concentration and related lending. They thus contribute to our understanding of portfolio credit risks of both individual financial institutions and whole financial systems (Powell et al., 2004).

Credit rating agencies have even developed risk assessment systems that automatically assess risk for small private companies. For instance, Moody’s “RiskCalc” models estimate one-year and five-year probabilities of default for European private companies relying on their financial statements. By providing a ready measure of private company credit risk, these systems allow better-informed credit decisions. ${ }^{29}$ More important, being automatic, they make it possible to evaluate, monitor and adjust the risk of lenders' portfolios in a matter of minutes. Experts can then focus on the high-risk loans that the model has identified as such. Trade and regulation are also made easier by having a single measure of risk (Kogacil et al., 2003; Moody’s KMV, 2007).

Since 2003, Moody's has adapted such models to the particular characteristics of the following European markets: Germany, Spain, France, the UK, Belgium, the Netherlands, Portugal, Italy, Austria, Denmark, Finland, Norway and Sweden. The datasets used to build these RiskCalc models are from companies smaller than the thresholds proposed by the European Commission: e.g., the model for Nordic Europe includes companies with more than $€ 0.1 \mathrm{~m}$ in

28 "The Committee permits banks a choice between two broad methodologies for calculating their capital requirements for credit risk. One alternative, the Standardised Approach, will be to measure credit risk in a standardised manner, supported by external credit assessments.... In determining the risk weights in the standardised approach, banks may use assessments by external credit assessment institutions recognised as eligible for capital purposes by national supervisors” (BIS, 2006: 19).

${ }^{29}$ Not only for deciding on loan applications but also for establishing more precise risk premiums and even establishing market transfer prices for loans made by parent companies to their subsidiaries. 
total assets; for the UK, those with more than $£ 0.1 \mathrm{~m}$ in total assets; for most other EU countries, those with turnover greater than $€ 0.5 \mathrm{~m}$.

Furthermore, despite being well below the European Commission’s thresholds for micro entities, RiskCalc thresholds are relatively high when considering that many banks apply them to firms of all sizes. RiskCalc models omit micro companies because, in order to use the models as stand-alone tools, they rely fully on quantitative data. However, the credit rating systems developed and applied internally by banks typically make use of both qualitative and quantitative data, so that for micro companies they can balance the lower accuracy of their quantitative data by giving more weight to qualitative data (on, e.g., management quality or succession plans). Apparently, banks find it informative to complement such qualitative data with quantitative data, mainly the published accounts of even the smallest companies.

Considering this extensive use of micro and small private companies' accounts, a reduction in the number of firms filing them would make estimating credit risk substantially more difficult because defaults are rare, a fact that already calls for using data from the last few years when estimating default probabilities. In particular, to the extent that smaller firms would cease filing reports, the thresholds for the models relying purely on quantitative data would be raised, and their coverage would consequently be reduced. The size of the EU and USA RiskCalc datasets gives us a glimpse of the likely change. As a consequence of the EU rule of mandatory publication of accounts by private and not only public companies, the European adaptations of the model rely on the accounts of many more companies than in the USA. Whereas, for example, the French model is based on 297,000 firms and the Spanish model is based on 140,790 firms, the USA model is based on only 40,000 firms.

Considering that most of large banks’ risk-about 50-60\%-is credit risk, with market and operational risks taking the remainder (Kuritzkes, Schuermann and Weiner, 2003), reducing the set of information has serious consequences for assessing banks' risk. It is therefore understandable that the European Committee of Central Balance Sheet Data Offices should have reacted strongly against the EC's proposal, considering that, in this new regulatory context, “the availability of an accounting and reporting framework that meets the requirements of banks is a 
cornerstone of a successful implementation of the new European prudential framework" (ECCBSO, 2007: 2). ${ }^{30}$

\subsection{Externalities in national accounting}

When building the financial accounts of national economies, many central banks rely partly on the financial statements of non-financial firms, mainly to produce information on their financial operations. Some countries have developed specific databases of accounts, to which firms send their accounts voluntarily, getting in return privileged access to aggregate information on their industry and the economy.

Participation, however, tends to be low and suffers from several biases-e.g. large firms are more inclined to participate. This makes it necessary to complement the analysis of their own databases with the accounts of small companies. For instance, the Bank of Spain’s database, which contained only 8,923 accounts in 2004, used for this purpose the accounts of 441,859 small companies filed at the Companies’ Register (Banco de España, 2006: 190). Without mandatory disclosure, it is doubtful how many of these accounts would be available.

\section{Who should balance costs and benefits?}

We have seen in previous sections that deciding on the publication of accounts-both whether to publish them or not and which contents to publish-entails costs and benefits. We will consider in this section alternative ways of trading off such costs and benefits: decisions by

\footnotetext{
30 The ECCBSO was set up in November 1987 on the initiative of several European central banks and the European Commission to "to improve the analysis of company data through the exchange of information, comparison of analytical methods and joint studies. It is composed of institutions from twelve European Union Member States and European Commission and OECD” (http://ec.europa.eu/economy_finance/indicators/bachdatabase_en.htm, visited on October 14, 2007).
} 
individual companies, both independently and through private collective arrangements, and government intervention to mandate publication and standardise the information to be published.

\subsection{Do firms balance costs and benefits well?}

Voluntary decisions by rational decision makers may deviate from the optimal trade-off of costs and benefits for two main reasons: the asymmetric structure of the information available and the presence of externalities. In addition, this balancing of costs and benefits may also be hindered when the decision maker deviates from rationality.

\subsubsection{Information asymmetry constraints}

In situations of information asymmetry, parties who are better informed may tend to voluntarily disclose their information to uninformed parties to avoid their inferring the worst and reacting accordingly, withdrawing their cooperation or taking precautionary measures (Grossman, 1981; Grossman and Hart, 1981; Milgrom, 1981). Some evidence on the presence of incentives for voluntary disclosure by private firms is provided, ${ }^{31}$ for instance, by the common practice of credit rating agencies, of using as an indicator of creditworthiness the fact that a company keeps all sorts of registrations up to date: from its listing in the telephone directory to its file in the company register.

Informed parties may not disclose the information, however, when one of the following assumptions does not hold: (1) When disclosure is costly, the possibility that uninformed trading parties will infer the worst from nondisclosure does not necessarily provide enough incentives to disclose (Jovanovic, 1982; Verrechia, 1983; Dye, 1986). (2) For the same reason, a similar outcome arises when it is not publicly known if the informed party is well informed or not (Matthews and Postlewaite, 1985; Farrell, 1986; Shavell, 1994). (3) When not all uninformed

\footnotetext{
31 Evidence for public companies was given in n. 18.
} 
parties understand the information, their lack of understanding may limit the benefits of disclosure for good firms and firms may end up in a nondisclosure equilibrium (Grossman, 1981; Fishman and Hagerty, 2003). (4) When the informed party cannot disclose all information (for instance, because it would have to prepare several sets of financial statements using different principles, which would be prohibitively expensive), a rule constraining disclosure choice will increase the value of the disclosed information (Fishman and Hagerty, 1990).

For disclosure of financial statements by private small companies, three of these assumptions do not hold, hindering voluntary disclosure. First, disclosure is costly, which may deter voluntary disclosure and cause confusion in the signal sent by non- disclosure. Second, it is public knowledge that companies have financial statements, which they use for their own management, so the second assumption does not hold. Third, a substantial proportion of market participants probably do not fully understand the accounts. Fourth, mandatory accounting principles are needed to increase the value of the information by limiting discretion.

Our survey of users of the main business information service in Spain supports the claim that the signal sent to potential trading partners by not filing is ambiguous (Table 1). Of all respondents, $57.43 \%$ consider the fact that a company has not filed its accounts as a bad sign. However, $41.58 \%$ do not conclude anything because they agree there may be many reasons for not publishing the accounts. Consequently, they simply try to gain additional information. Certainly, a majority of respondents considered failure to file as a bad signal. ${ }^{32}$ However, our respondents are a subsample of the population of economic agents using these information systems. Moreover, they are judging the failure to file in an environment of mandatory filing, in which failure to file is not prevalent among active companies (informal estimates run from 10 to $20 \%$ ). One could assume that their judgement would be more lenient under voluntary filing, mirroring greater ambiguity of failing to file. The consequence would be fewer incentives to file.

32 Unreported regression analysis shows that larger firms are more benign when interpreting failure to file the accounts, whereas older firms and those which file their accounts earlier in the year tend to give a worse rating to firms which have failed to file theirs. 


\subsubsection{Difficulties for internalising externalities}

The most important reason for suboptimal disclosure is the presence of externalities: firms lack incentives to voluntarily disclose the optimal amount of information, given that they internalise some but not all the social benefits of disclosure. ${ }^{33}$ Furthermore, the use of computers and the Internet has increased the value of these externalities by making it possible to aggregate the information in the accounts and to distribute the information to millions of users more cheaply and promptly.

However, the presence of externalities does not necessarily require a public solution. In the spirit of Coase (1960), we need to examine the comparative performance of mandatory disclosure as compared to voluntary disclosure under alternative solutions, such as private sector collective agreements that may internalise externalities in unorganised voluntary disclosure and offer the potential advantage of being more adaptive.

In particular, information intermediaries can be developed by firms and industry associations to process firms' information, allowing externalities to be obtained but minimising the costs for the firms themselves. Such intermediaries can produce aggregate indicators for the industry or even partial indicators for individual firms without disclosing sensitive information: for instance, they can rate firms' solvency without disclosing detailed information, as done by the "RiskCalc" system in the USA, as explained in section 4.2.

These private arrangements are less viable for private than for public companies, however. Their operation depends for their success on firms' cooperation and it is likely that a greater number of firms will make it more difficult for them to agree and enforce their agreements on

33 This goes even for authors that are generally sceptical about the overall merits of financial regulation. For example, Zingales considers that "we can identify three areas where intervention is needed. First, in the area of disclosure: companies tend to have too little incentive to disclose" (2004: 40). (In some circumstances, however, firms may also disclose too much information [Fischman and Hagerty, 1989].) Some other rationales for mandatory disclosure, such as protecting small investors or increasing confidence in capital markets, enjoy less unanimous support in the literature. Compare, e.g., Easterbrook and Fischel (1991: 296-300) with the studies cited in n. 5. We skip discussion of these studies here because they do not apply to private small companies, which do not sell securities in the market and, 
sharing information. For smaller firms, such information intermediaries are less likely fail to exist or will tend to provide incomplete and inaccurate information for a lower number of firms, as illustrated by experiences such as that of RiskCalc in the USA (section 4.2) or the Bank of Spain (section 4.3).

In particular, voluntary arrangements suffer a serious bias in terms of self-selection if firms in distress are more likely not to cooperate. ${ }^{34}$ This is potentially very damaging because statistical models for assessing credit risk rely on a relatively small number of defaults. And this is not the only bias in the willingness to provide information. For example, financial institutions are often willing to build private databases with negative information on payment but they are less willing to share positive information, probably because they do not want to risk losing their good clients. However, including positive information significantly improves the estimation of credit risk, leading to access to credit for more borrowers when positive information is included (Powell et al., 2004).

Considering these factors, it seems that voluntary disclosure might work better for private large companies than for private small companies, because both the costs of disclosure may be larger and the benefits easier to reach by voluntary disclosure for large private firms than for small private firms. Many large private firms produce differentiated products and are active in concentrated markets, so disclosure is more likely to damage their competitive position. Also, with a small number of firms it is easier to overcome collective action problems and reach industry-wide externalities by agreeing to voluntary disclosure. On the contrary, small firms are more often in competition. And there are often huge numbers of them in any industry, making such voluntary agreements much more difficult to reach and enforce.

given their small size, the reputational effect of their eventual failure or fraudulent behaviour would in any case be very limited.

34 As suggested by the finding that firms doing well disclose more (Lang and Ludholm, 1993). 


\subsubsection{Deviations from rationality}

So far, we have been assuming that companies are able to rationally evaluate the costs and benefits of publishing their accounts. Let us now consider some possible deviations from rationality.

First, companies are not individuals. Therefore, rational calculation by managers may lead to irrational decisions by their firms if managers’ interests are misaligned with those of shareholders in maximising the value of the firm. This is a serious problem for companies with separation of ownership and control. In fact, many discussions on mandatory disclosure focus on the conflict between managers and shareholders, and try to elucidate how mandatory regulation may affect their ability to contract for optimal disclosure. For small private companies, this is a minor problem, however, given that we can confidently assume little separation between ownership and control.

Second, we could argue that manager-owners of private small companies are not always capable of correctly weighing the costs and benefits of publishing their accounts. There is no doubt that many of them often fail in this (and many other) calculations. Cognitive research has discovered many systematic biases in decision-making. For instance, in this area, one could easily imagine the possible presence of "status quo bias" hindering adaptation to the fact that the Internet has made credit information easier to aggregate and circulate, therefore enhancing benefits. Also, especially for very small companies wishing to file, an external mandatory rule can save them a cost in terms of exerting self-control. Nonetheless, whatever the importance of these biases, it is unclear what role should be taken by the government in easing them, mainly because decision makers in government also suffer similar biases and private decision makers often have better incentives for learning how to overcome them. ${ }^{35}$

\footnotetext{
35 Moreover, cognitive arguments open the door to explanations in all directions. For instance, Arya and Mittendorf explain, on the basis of herding behaviour amongst third-party information providers, why voluntary disclosure may benefit the discloser even though the information directly benefits competitors, by guiding the information gathering and dissemination amongst these third parties. "Roughly stated, the infusion of early precise information can have a domino effect on followers, leading to a consensus view that does a poor job of reflecting the diversity of information” (2005: 232).
} 
Third, individuals may be perfectly rational in evaluating costs and benefits but may be pressured by maladapted social norms to behave in accordance with the norm. This may happen, for instance, if the norm imposes additional costs (e.g. a reputational loss) on those who do not comply with it. ${ }^{36}$ Bainbridge (2000) argues that a social norm of suboptimal disclosure-rooted in herding and conformity behaviour-may define a bad collective equilibrium of low voluntary disclosure in a financial market. In such situations, a rule of mandatory disclosure could take society to a hopefully more efficient equilibrium.

The argument is important because the financial markets of many member states, especially the new member states of the EU, are emerging markets with closely-knit business communities in which privacy is still a predominant social norm. ${ }^{37}$ Under the pressure of this social norm, it is less likely that mandatory disclosure would be promulgated by the state, if given the freedom to decide. Furthermore, it is also less likely that companies would voluntarily disclose optimally. ${ }^{38}$

\subsection{Do governments balance costs and benefits better than firms?}

Firms' inability to produce externalities, especially when these are as substantial as those existing today regarding credit information, makes a mandatory rule of account publication potentially efficient. This efficiency hinges, however, on the actual ability of government to both minimise costs and maximise benefits. Mandatory publication would not be efficient if the costs of filing the accounts are disproportionate nor the system is structured in a way that does not ensure reliability or does not allow utilisation of the information in the public files.

\footnotetext{
36 The aversion to disclosure in Chinese business circles was weighted when exempting small companies from publication in Hong Kong (SCCLR, 2000: 195).

37 The importance of this emerging-markets dimension of the problem is compounded in the light of the evidence provided by Djankov, McLiesh and Shleiter (2007) who show that in less developed countries credit volume depends relatively more on the ex ante availability of information on debtors' quality than on the strength of creditors' rights.

38 Different social norms are in place within the EU in many areas, one such being payment periods and payment delays (Arruñada, 1999a, 1999b, 2000), which have led to the issue of Directive 2000/35/EC to
} 
Company registers are the key agencies responsible for this efficiency, as they are the recipients, holders and primary issuers of account information. Even company registers which are less active in checking the legality of corporate transactions need to be reliable with respect to the date of filing and the storage of the accounts. To avoid potential damages to their parties, registers' independence is preserved by granting them a monopoly position, so that companies cannot choose a "register of convenience” (Arruñada, 2003). Understandably, this monopoly position often makes it harder to reduce the cost of filing the accounts and enhance the value of the information. 39

The key element is the efficient functioning of electronic systems for filing and retrieving information, not only on an individual basis but also in batches, thus allowing the operation of filing and information intermediaries who compete in developing well- adapted interfaces with users. Because there is a substantial fixed component in the cost of filing, in order to reduce the cost of filing for small firms they should be allowed to file through their accountants and other providers of tax, legal and administrative services, without any specific involvement of the companies’ legal representatives. In addition, costs can be reduced by unifying the different accounts to be filed for different purposes, or at least establishing standards that allow accounting software to produce different sets of accounts automatically for different purposes.

combat late payment in commercial transactions and achieve greater harmonisation in the internal market.

39 The need for a speedy register is clear when considering that cost and value are in conflict: more recent accounts are more informative for users but filing sooner is also costlier for filers. This trade-off is illustrated by the failure of the 2006 UK Companies Act to substantially reduce the filing period. The final wording of section 442 shortened it from 10 to 9 months for private companies. However, the White Paper for the UK's Company Law Reform Bill of 2005 had proposed to reduce filing times to 7 months because, according to small business organisations, the increase in costs "would not adversely affect work patterns.... [and] be of benefit to third-party small company users of those accounts” (DTI, 2005: 281). 


\subsection{If government, which government? Cross-border effects of credit information services}

Even though the European Commission considers that "harmonised accounting requirements are needed for cross-border investments and company operations also for many small companies” (EC, 2007: 15), the Commission does not make explicit its view on the cross-border effect of companies' publication of accounts. Given the Commission's proposal to exempt micro and small companies from mandatory publication of accounts, the Commission seems, however, to assume implicitly that this exemption would not entail relevant cross-border effects. In particular, it seems to assume that effects on transparency for third parties are only relevant for the mobility of companies but not for the mobility of goods and services.

Both assumptions are doubtful, as many micro and small private companies are involved in cross-border trade. According to the last row of Table 5 in the Annex, 4.65\% of micro companies and $16.29 \%$ of small companies are involved in cross-border trade. These micro and small companies do benefit from the increased transparency provided by a harmonised policy regarding publication of accounts. As examined above, such benefit comes both directly, by offering access to the accounts, and indirectly, by facilitating greater development of information systems that assess and report on private companies' credit risk. It is also revealing that in our sample users of a Spanish business information system, we find that firms more involved in cross-border trade tend to use the information more to grant credit to both new and old clients, and to sell in new regions (models 3 to 5 in Table 3).

In essence, the beneficial effects of account publication on the cost of credit apply more to small firms in cross-border than in domestic transactions because for domestic transactions banking networks provide a palliative solution but for cross-border transactions there are no international banking networks at the retail level. Imagine a Swedish bank buying bills of exchange or entering into a factoring agreement with a Swedish client who is supplying a Portuguese customer on credit. For the bank and its client, information on the credit rating of the foreign partner is hard to obtain because Swedish banks have little retail activity in Portugal, if any. Information from the published accounts and from the reports provided by credit information agencies services that heavily rely on them is therefore more valuable for smaller than for larger companies. 
This effect may seem irrelevant because the current volume of cross-border trade by micro firms is small. However, the important question is why it is small and how to reduce the barriers that keep it small. The discussion leading to the adoption of the Directive on payment delays throws some light on this, as exporters in Nordic countries complained persistently about how unreliable Southern European firms were in matters of both payments and delays (Arruñada, 1999a, 1999b, 2000). In such a context, the availability of standardised information that allows good risks to distinguish themselves from bad risks is important for competition (and even for ascertaining the truth in potentially damaging stereotypes).

Certainly, this argument supports mandatory publication only to the extent that private incentives are insufficient, especially for cross-border trade by small firms, given its currently incipient level. These small foreign trade pioneers produce positive externalities for their competitors in the same industry, region and country. Therefore, their incentives to start are suboptimal, including their incentives to take the necessary steps, such as more open disclosure. Furthermore, for such pioneer firms the costs of disclosure might be substantial if disclosure damages their competitive position in the-initially more important—domestic market. A collective action trap may find firms in a bad equilibrium in which no firm is willing to pioneer because most profits would accrue to its competitors.

Moreover, Member States could try to avoid this trap by imposing mandatory publication at the national level. That is, in our example, the Portuguese Government would impose mandatory publication on Portuguese firms, so solving their collective action problem. Proximity to Portuguese firms might help in evaluating their costs and benefits but might also bias the political consideration of any costs and benefits. In the end, political decisions also depend on the relative strength of the different interests in place, whatever their merit from a public perspective. To the extent that mandatory publication would increase competition in the Portuguese market (by, for instance, facilitating credit for importers), it is easy to imagine that many agents might oppose it based on their private interests, even though it is socially 
beneficial. ${ }^{40}$ In general terms, it is unclear which level of government— European or nationalis better placed to reach market-enhancing decisions on this issue. ${ }^{41}$

In fact, decision rights on this issue are shared amongst European and national institutions in a way that, given their interests, probably allows them to make the best use of available specific information (Hayek, 1945). European decision makers, who are more interested than national ones in developing cross-border competitive markets, are probably well placed to pursue the benefits of this policy, whereas national decision makers may be more influenced by its costs. The current system allocates decision rights on benefits to Brussels regarding which accounts are published by whom, but decision rights on costs to national governments, which implement and manage the account filing systems whose performance determines the level of most costs.

\section{Concluding remarks}

The cost and benefit analysis in this article advises against simplification policies that would reduce the scope of mandatory publication of private company accounts. Instead, it encourages policies that aim to reduce costs and enhance value through administrative reforms of filing, archive and retrieval systems. Policies should exploit the possibilities that new information technologies offer to use the accounts in assessing the credit risk of even very small firms, therefore reducing their cost of credit and expanding trade opportunities.

It is true that publishing accounts incurs administrative costs, but these are not high and can be reduced further by electronic filing. Other costs, such as possible distortions in competition and the erosion of privacy are immaterial or doubtful, especially for micro and small companies.

\footnotetext{
40 Easterbrook and Fischel recognize that competition among USA states cannot produce optimal solutions in the presence of interstate effects (1991: 295, 300-2, 304-5): some states would tend to be holdouts to benefit their firms.

${ }^{41}$ In addition, the presence of sunk costs may also motivate substantial rent-seeking activities. (Or, more precisely, “quasi-rent-seeking” activities). It might therefore be more wasteful to apply the subsidiarity principle in this area, whatever the decision taken by the European Union.
} 
First, the cost to the disclosing firm of informing its competitors seems unlikely to be substantial when small companies are involved. Damage to privacy is elusive and hard to evaluate because most positive law does not grant privacy rights to corporations. Moreover, much of the demand for company privacy is directed at tax evasion and fraud, and therefore has little merit from a social perspective.

On the other hand, publishing accounts lessens information asymmetry with other firms. This effect has always been present but has become stronger due to credit information systems based on computerised databases and universal Internet access. Status reports based on these systems are thus reducing the cost of credit for small firms, enhancing competition in product and credit markets, and expanding trade and specialisation. Furthermore, small companies are the main beneficiaries of these credit information systems, as shown by two figures: about $95 \%$ of both their primary and secondary demand is for information on small companies; and in our survey $89 \%$ of final users declare they use such systems to find out about small firms.

Moreover, publishing company accounts produces substantial externalities, especially in credit assessment and financial regulation, because firms do not internalise all the benefits of publishing their accounts. Private arrangements are unlikely to reach an acceptable production of such externalities, especially for small firms and due to the collective action problem inherent in such a massive number of firms. Most of the externalities would therefore be lost in a regime of voluntary publication. Consequently, credit risk assessments would cover fewer firms and would be less accurate even for the firms that do publish their accounts, posing an acute free-riding problem.

Overall, it seems viable for governments to structure company registers to achieve a more efficient trade-off of costs and benefits than would be possible with a regime of voluntary publication.

In addition to throwing light on the policy discussion on the regulation of accounting disclosure by private companies, this article contributes to different strands of economics, accounting and finance. First, the article shows once again that deregulation policies that narrowly focus on reducing the cost of institutional arrangements, such as those sponsored by the World Bank’s Doing Business, may be counterproductive when they disregard the value of the services being provided. Second, by focusing on private companies, the article complements the 
literature on mandatory financial disclosure, which has mainly focused on the effects that financial disclosure by public companies exerts on equity transactions. Third, it also confirms that the main benefit of disclosure by private companies is to reduce information asymmetry in credit transactions. This suggests that the opportunities and regulatory problems involved are more of the type posed by credit bureaus than those of conventional corporate disclosure, which is more oriented to stock market transactions. Lastly, compared to the literature on mandatory financial disclosure by public companies, the article suffers from the lack of stock market prices, which makes it well nigh impossible to measure effects on firm value. The article, however, provides survey evidence that also confirms empirically such beneficial effects on credit transactions. 


\section{References}

Admati, Anat R., and Paul Pfleiderer (2000), "Forcing Firms to Talk: Financial Disclosure Regulation and Externalities,” Review of Financial Studies,13(3), 479-519.

Aghion, Philippe, and Patrick Bolton (1992), “An Incomplete Contracts Approach to Financial Contracting,” Review of Economic Studies, 59(3), 473-494.

Altman, Edward (1968), "Financial Ratios, Discriminant Analysis and the Prediction of Corporate Bankruptcy,” Journal of Finance, 23(4), 589-609.

Arruñada, Benito (1999a), Aplazamiento de pago y morosidad en las transacciones comerciales, Marcial Pons, Madrid.

Arruñada, Benito (1999b), La Directiva sobre morosidad: Una mala solución para un falso problema, Marcial Pons, Madrid.

Arruñada, Benito (2000), “The Quasi-Judicial Role of Large Retailers: An Efficiency Hypothesis of their Relation with Suppliers,” Revue d'Economie Industrielle, 92, 277-296.

Arruñada, Benito (2003), “Property Enforcement as Organized Consent,” Journal of Law, Economics, and Organization, 19(2), 401-444.

Arruñada, Benito (2007), "Pitfalls to Avoid when Measuring the Institutional Environment: Is Doing Business Damaging Business,” Journal of Comparative Economics, 35(4), 729-747.

Arruñada, Benito (2008), “Will Doing Business Keep Damaging Business,” Journal of Comparative Economics, forthcoming.

Arruñada, Benito, Luis Vázquez, and Giorgio Zanarone (2008), “Agency Costs and Environmental Constraints in Governance Choice: The Case of Automobile Distribution in Spain,” Managerial and Decision Economics, forthcoming.

Arya, Anil, and Brian Mittendorf (2005), "Using Disclosure to Influence Herd Behavior and Alter Competition,” Journal of Accounting and Economics, 40(1-3), 231-246.

Arya, Anil, Jonathan C. Glover, and Shyam Sunder (2003), “Are Unmanaged Earnings Always Better for Shareholders?,” Accounting Horizons, 17(s1), 111-116.

ASEDIE, Asociación Multisectorial de la Información (2007), “Informe sobre la propuesta de la Comisión Europea de simplificación del derecho de sociedades, de la contabilidad y de la auditoría,” Madrid, October 10.

Bainbridge, Stephen M. (2000), “Mandatory Disclosure: A Behavioral Analysis,” University of Cincinnati Law Review, 68, 1023-1060.

Ball, Ray, and Lakshmanan Shivakumar (2005), "Earnings Quality in UK Private Firms: Comparative Loss Recognition Timeliness,” Journal of Accounting and Economics, 39(1), 83-128. 
Banco de España (2006). Central de balances: Resultados anuales de las empresas no financieras 2005, Banco de España, Madrid (http://www.bde.es/informes/be/cb/cb.htm, visited October 10, 2007).

Barron, John M., and Michael Staten (2003), “The Value of Comprehensive Credit Reports: Lessons from the U.S. Experience,” in Margaret J. Miller, ed., Credit Reporting Systems and the International Economy, Boston, MIT Press, 273-310.

Barry, Phillip (2006), "Financial Disclosure: An Economic Analysis,” in OCDE, Corporate Governance of Non-Listed Companies in Emerging Markets, OCDE, Paris, 19-38.

Barton, Jan, and Gregory Waymire (2004), “Investor Protection under Unregulated Financial Reporting,” Journal of Accounting and Economics, 38(1-3), 117-128.

Benston, George J., and Clifford W. Jr. Smith (1976), “A Transactions Cost Approach to the Theory of Financial Intermediation,” Journal of Finance, 31(2), 215-231.

Bhattacharya, Utpal, Hazem Daouk, and Michael Welker (2003) "The World Price of Earnings Opacity,” Accounting Review, 78(3), 641-678.

BIS, Bank of International Settlements (2006), International Convergence of Capital Measurement and Capital Standards: A Revised Framework-Comprehensive Version, Basel Committee on Banking Supervision, Basel, June. Available at http://www.bis.org/publ/bcbs128.htm (visited October 15, 2007).

Bodie, Matthew T. (2006). “Information Disclosure and the Union Representation Election,” $B$. E. Press Legal Service Series, paper 1158. Available at http://law.bepress.com/cgi/viewcontent.cgi?article=5503\&context=expresso (visited October 4, 2007).

Bollen, Laurentius H. H. (1996), "Financial Reporting Regulation for Small and Medium Sized Private Firms: An empirical analysis of compliance, perceptions, costs, and usefulness," PhD Dissertation, University of Limburg, Maastricht, January 18, http://www.personeel.unimaas.nl/L.Bollen/articles/Dissertation_Bollen.pdf (visited October 13, 2007).

Bushee, Brian J., and Christian Leuz (2005), “Economic Consequences of SEC Disclosure Regulation: Evidence from the OTC Bulletin Board,” Journal of Accounting and Economics, 39(2), 233-264.

Choi, Stephen (2000), “Regulating Investors Not Issuers: A Market-Based Proposal,” California Law Review, 88(2), 279-334.

Chow, Chee W. (1983), “The Impacts of Accounting Regulation on Bondholder and Shareholder Wealth: The Case of the Securities Acts,” The Accounting Review, 58(3), 485-520.

Claessens, Stijn, and Konstantinos Tzioumis (2006), “Ownership and Financing Structures,” chapter 2 in OCDE, Corporate Governance of Non-Listed Companies in Emerging Markets, OCDE, Paris and Washington, D.C., 39-63.

CLRC, Corporate Law Reform Committee (2007), “A Consultative Document Creating a Conducive Legal and Regulatory Framework for Businesses,” January, Kuala Lumpur, Malaysia, http://www.ssm.com.my/clrc/cd6.pdf (visited October 20, 2007). 
CLRFC Company Legislation and Regulatory Framework Committee (2002), Final Report, Company Legislation and Regulatory Framework Committee, Singapore, October http://www.mof.gov.sg/cor/clrfc_reports.html (visited October 20, 2007).

CLRSG, Company Law Review Steering Group (2000), “Modern Company Law for a Competitive Economy: Developing the Framework,” March, http://www.dti.gov.uk/bbf/coact-2006/clr-review/page25086.html (visited October 20, 2007).

Coase, Ronald H. (1960), “The Problem of Social Cost,” Journal of Law and Economics, 3, 144.

Coface (2007), “Historique.” Available at http://www.coface.fr/CofacePortal/redirection.jsp?pageId=pages/home/wwa/gt/highlights\&s ite=FR_fr_FR, visited October 15, 2007).

Coffee, John C. (1984), "Market Failure and the Economic Case for a Mandatory Disclosure System,” Virginia Law Review, 70(4), 717-753.

De Servigny, Arnaud, and Olivier Renault (2004), Measuring and Managing Credit Risk, McGraw-Hill, New York.

Depoers, Florence (2000), “A Cost-Benefit Study of Voluntary Disclosure: Some Empirical Evidence from French Listed Companies,” European Accounting Review, 9(2), 245-263.

DGRN, Dirección General de los Registros y del Notariado (several years), Anuario de la Dirección General de los Registros y del Notariado, Ministry of Justice, Madrid.

Diamond, Douglas W., and Robert E. Verrecchia (1991), "Disclosure, Liquidity, and the Cost of Capital,” Journal of Finance, 46(4), 1325-1359.

Djankov, Simeon (2008), “A Response to ‘Is Doing Business Damaging Business’,” Journal of Comparative Economics, forthcoming.

Djankov, Simeon, Caralee McLiesh and Andrei Shleifer (2007), "Private Credit in 129 Countries,” Journal of Financial Economics, 84(2), 299-329.

Djankov, Simeon, Rafael La Porta, Florencio Lopez-de-Silanes and Andrei Shleifer (2002), “The Regulation of Entry,” Quarterly Journal of Economics, 117(1), 1-37.

DTI, Department of Trade and Industry (2005), Company Law Reform, Presented to Parliament by the Secretary of State for Trade and Industry by Command of Her Majesty, March 2005, http://www.berr.gov.uk/files/file13958.pdf (visited October 20, 2007).

Dye, Ronald A. (1986), "Proprietary and Nonproprietary Disclosures,” Journal of Business, 59(2), 331-366.

Easterbrook, Frank. H., and Daniel R. Fischel (1984), "Mandatory Disclosure and the Protection of Investors,” Virginia Law Review, 70(4), 669-715.

Easterbrook, Frank. H., and Daniel R. Fischel (1991), “Mandatory Disclosure,” chapter 11 in The Economic Structure of Corporate Law, Harvard University Press, Cambridge, MA, 286-314. 
ECCBSO, European Committee of Central Balance-Sheet Data Offices (2007), “Opinion of ECCBSO to the Communication from the European Commission on Simplified Business Environment for Companies in the Areas of Company Law, Accounting and Auditing (COM 2007394 final)," October.

European Charter for Small Enterprises (2000), Approved by EU Leaders at the Feira European Council on 19-20 June 2000, http://europa.eu.int/comm/enterprise/enterprise_policy/charter/index_en.htm (visited 4 October 2007).

European Commission (2007), Communication from the Commission on a Simplified Business Environment for Companies in the Areas of Company Law, Accounting and Auditing, COM(2007) 394 final, Brussels, July 10, http://ec.europa.eu/internal_market/company/docs/simplification/com2007_394_en.pdf (visited 4 October 2007).

Farrell, Joseph (1986), “Voluntary Disclosure: Robustness of the Unraveling Result, and Comments on its Importance,” in R. Grieson, ed., Antitrust and Regulation, Lexington Books, Lexington MA, 91-103.

Fishman, Michael J., and Kathleen M. Hagerty (1990), “The Optimal Amount of Discretion to Allow in Disclosure,” Quarterly Journal of Economics, 105(2), 427-444.

Fishman, Michael J., and Kathleen M. Hagerty (2003), “Mandatory versus Voluntary Disclosure in Markets with Informed and Uninformed Customers," Journal of Law, Economics, and Organization, 19(1), 45-63

Francis, Jere R., Inder K. Khurana and Raynolde Pereira (2005), “Disclosure Incentives and Effects on Cost of Capital around the World," Accounting Review, October 2005, 80(4), 1125-1162.

Freixas, Xavier, and Jean-Charles Rochet (1997), Microeconomics of Banking, MIT Press, Cambridge, MA.

Giner Inchausti, Begoña (1997), “The Influence of Company Characteristics and Accounting Regulation on Information Disclosed by Spanish Firms,” European Accounting Review, 1997, 6(1), 45-68.

Gore Angela, Kevin Sachs, and Charles Trzcinka (2004), "Financial Disclosure and Bond Insurance,” Journal of Law and Economics, 47(1), 275-306.

Gore, Angela K. (2004), “Does Mandatory Disclosure Reduce the Cost of Capital? Evidence from Bonds,” Lundquist College of Business, University of Oregon, July 12. Available at http://ssrn.com/abstract=565182 (visited October 4, 2007).

Graham John R., Campbell R. Harvey and Shiva Rajgopal (2005), “The Economic Implications of Corporate Financial Reporting,” Journal of Accounting and Economics, 40(1-3), 3-73.

Granovetter, Mark (1985), "Economic Action and Social Structure: The Problem of Embeddedness,” American Journal of Sociology, 91(3), 481-510.

Greenstone Michael, Paul Oyer, and Annette Vissing-Jorgensen (2006), "Mandated Disclosure, Stock Returns, and the 1964 Securities Acts Amendments," Quarterly Journal of Economics, 121(2), 399-460. 
Grossman, Sanford J., and Oliver D. Hart (1980), "Disclosure Laws and Takeover Bids,” Journal of Finance, 35(2), 323-334.

Grossman. Sanford J. (1981), “The Informational Role of Warranties and Private Disclosure about Product Quality,” Journal of Law and Economics, 24(3), 461-483.

Hail, Luzi (2002), "The Impact of Voluntary Corporate Disclosures on the Ex-Ante Cost of Capital for Swiss Firms,” European Accounting Review, 11(4), 741-773.

Hall, Thomas W. (2006), "National Variation in Financing Patterns,” chapter 3 in OCDE, Corporate Governance of Non-Listed Companies in Emerging Markets, OCDE, Paris, 6590.

Hannon Neal J., and Robert J. Gold (2005), “XBRL Revisited,” Journal of Accountancy, 199(2), 64-65.

Hansmann, Henry, Reinier Kraakman, and Richard Squire (2005), “The New Business Entities in Evolutionary Perspective,” Illinois Law Review, 2005(1), 5-14.

Hart, Oliver, and John Moore, (1994) "A Theory of Debt Based on the Inalienability of Human Capital,” Quarterly Journal of Economics,109(4), 841-879.

Hart, Oliver, and John Moore, (1998) "Default and Renegotiation: A Dynamic Model of Debt," Quarterly Journal of Economics, 113(1), 1-41.

Hayek, Friedrich A. (1945), “The Use of Knowledge in Society”, The American Economic Review, 35(4), 519-530.

Healy, Paul M., and Krishna G. Palepu (2001), “Information Asymmetry, Corporate Disclosure, and the Capital Markets: A Review of the Empirical Disclosure Literature,” Journal of Accounting and Economics, 31(1-3), 405-440.

Informa, S.L. (2007), “Quienes somos,” available at http://www.informa.es/infornet/Main/idioma/01/screen/SShowPage/pagina/quienessomos.ht

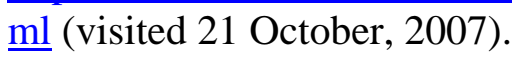

Jaffee, Dwight M., and Thomas Russell (1976), “Imperfect Information, Uncertainty and Credit Rationing,” Quarterly Journal of Economics, 90(4), 651-666.

Jovanovic, Boyan (1982), “Truthful Disclosure of Information,” Bell Journal of Economics, 13(1), 36-14.

Kallberg, Jarl G., and Gregory F. Udell (2003) “The Value of Private Sector Business Credit Information Sharing: The US Case,” Journal of Banking \& Finance, 27(3), 449-469.

Kocagil, Ahmet E., Nicole Seiberlich, Özveri Teymur, Angelina Grass, Edward Parillon, Phil Escott, and Frank Glormann (2003), "Moody’s RiskCalc ${ }^{\mathrm{TM}}$ For Private Companies: Nordic Region,” Moody’s Investors Service, Inc., Report 7771, April.

Kuritzkes, Andrew, Til Schuermann and Scott M. Weiner (2003), “Risk Measurement, Risk Management and Capital Adequacy of Financial Conglomerates,” in R. Herring and R. Litan, eds., Brookings-Wharton Papers in Financial Services, 141-194.

La Porta, Rafael, Florencio Lopez-de-Silanes, and Andrei Shleifer (1999), "Corporate Ownership around the World,” Journal of Finance, 54(2), 471-517. 
La Porta, Rafael, Florencio Lopez-de-Silanes, Andrei Shleifer, and Robert W. Vishny (1997), “Legal Determinants of External Finance,” Journal of Finance, 52(3), 1131-1150.

La Porta, Rafael, Florencio Lopez-de-Silanes, Andrei Shleifer, and Robert W. Vishny (2002), “Investor Protection and Corporate Valuation,” Journal of Finance, 57(3), 1147-1170.

Lang, Mark, and Russell Lundholm (1993), “Cross-Sectional Determinants of Analyst Ratings of Corporate Disclosures,” Journal of Accounting Research, 31(2), 246-271.

Leftwich, Richard (2004), “Discussion of: 'Investor Protection under Unregulated Financial Reporting',” Journal of Accounting and Economics, 38(1-3), 117-128.

Maijoor, Steven J. (1996), "Dutch accounting legislation and changes of organizational form: An efficient contracting perspective,” Journal of Accounting and Public Policy,” 15(2), 137160.

Matthews, Steven, and Andrew Postlewaite (1985), “Quality Testing and Disclosure,” RAND Journal of Economics, 16(3), 328-340.

Merton, Robert C. (1974), “On the Pricing of Corporate Debt: The Risk Structure of Interest Rates,” Journal of Finance, 29(2), 449-470.

Milgrom, Paul R. (1981), "Good News and Bad News: Representation Theorems and Applications,” Bell Journal of Economics, 12(2), 380-391.

Mitton, Todd, (2002), “A Cross-Firm Analysis of the Impact of Corporate Governance on the East Asian Financial Crisis,” Journal of Financial Economics, 64(2), 215-241.

Moody’s KPV (2007), “Moody’s KMV RiskCalc.” Available at http://www.moodyskmv.com/products/sa_riskCalc.html (visited October 5, 2007).

Nikolaev, Valeri, and Laurence Van Lent (2005), “The Endogeneity Bias in the Relation between Cost-of-Debt Capital and Corporate Disclosure Policy,” European Accounting Review, 14(4), 677-724.

North, Douglass C., and Robert P. Thomas (1973), The Rise of the Western World: A New Economic History, Cambridge, Cambridge University Press.

OCDE, Organisation for Economic Co-Operation and Development (2006), Corporate Governance of Non-Listed Companies in Emerging Markets, OCDE, Paris.

Pagano, Marco, and Tullio Jappelli (1993), “Information Sharing in Credit Markets”, Journal of Finance, 48(5), 1693-1718.

Pagano, Marco, Fabio Panetta, and Luigi Zingales (1998), "Why Do Companies Go Public? An Empirical Analysis,” The Journal of Finance, 53(1), 27-64.

PJSCCS, Parliamentary Joint Statutory Committee on Corporations and Securities (2001), "Report on Aspects of the Regulation of Proprietary Companies," Senate Printing Unit, Parliament House, Canberra, March, http://www.aph.gov.au/senate/committee/corporations_ctte/completed_inquiries/1999(visited October 20, 2007). 
Powell, Andrew P., Nataliya Mylenko, Margaret Miller, and Giovanni Majnoni (2004), "Improving Credit Information, Bank Regulation, and Supervision: On the Role and Design of Public Credit Registries,” World Bank Policy Research Working Paper No. 3443, November 2. Available at http://ssrn.com/abstract=625321 (visited October 3, 2007).

Raffournier, Bernard (1995), “The Determinants of Voluntary Financial Disclosure by Swiss Listed Companies,” European Accounting Review, 4(2), 261-280.

Rajan, Raghuram G., and Luigi Zingales (1998), “Financial Dependence and Growth,” American Economic Review, 88(3), 559-586.

Rajan, Raghuram G., and Luigi Zingales (2003), Saving Capitalism from the Capitalists, Random House, New York.

Romano, Roberta (1998), “Empowering Investors: A Market Approach to Securities Regulation,” Yale Law Journal, 107(8), 2359-2430.

Sapienza, Paola (2002), “The Effects of Banking Mergers on Loan Contracts”, Journal of Finance, 57(1), 329-367.

SCCLR, Standing Committee on Company Law Reform (2000), “The Report of the Standing Committee on Company Law Reform on the Recommendations of a Consultancy Report of the Review of the Hong Kong Companies Ordinance,” February 2000, Hong Kong, http://www.cr.gov.hk/en/standing/docs/16anrep.pdf (visited October 20, 2007).

Seabright, Paul (2004), The Company of Strangers: A Natural History of Economic Life, Princeton and Oxford, Princeton University Press.

Shavell, Steven (1994), “Acquisition and Disclosure of Information Prior to Sale,” RAND Journal of Economics, 25(1), 20-36.

Simon, Carol J. (1989), "The Effect of the 1933 Securities Act on Investor Information and the Performance of New Issues,” American Economic Review, 79(3), 295-318.

Stiglitz, Joseph, and Andrew Weiss (1981), "Credit Rationing in Markets with Imperfect Information,” American Economic Review, 71(3), 393-410.

TDC, Tribunal de Defensa de la Competencia (2005), "Resolución Expediente A 335/03, RAI/CCI,” Madrid, February 8.

Townsend, R., (1979), "Optimal Contracts and Competitive Markets with Costly State Verification,” Journal of Economic Theory, 21(2), 265-293.

UNCTAD (2005), International Accounting and Reporting Issues: 2004 Review, United Nations, Report by the Secretariat of the United Nations Conference on Trade and Development, Geneva.

UN-ECE, United Nations Economic Commission for Europe (2000), Study on Key Aspects of Land Registration and Cadastral Legislation, London, HMLR.

Vermeulen, Erik P.M. (2006), “The Role of the Law in Developing Efficient Corporate Governance Frameworks,” chapter 1 in OCDE, Corporate Governance of Non-Listed Companies in Emerging Markets, OCDE, Paris, 91-130.

Verrecchia, Robert E. (1983), “Discretionary Disclosure,” Journal of Accounting and Economics, 5(3), 179-194. 
Weilbach, E. (1991), "Vermeidung der Zwanslóschung einer GmbH nach Verweigerung der Registerpublizität,” Betriebs-Berater, 800-801.

World Bank, 2003. Doing Business in 2004: Understanding Regulation. World Bank and Oxford University Press, Washington DC.

World Bank, 2004. Doing Business in 2005: Removing Obstacles to Growth. World Bank and Oxford University Press, Washington DC.

World Bank, 2005. Doing Business in 2006: Creating Jobs. World Bank and Oxford University Press, Washington DC.

World Bank, 2006. Doing Business 2007: How to Reform. World Bank and Oxford University Press, Washington DC.

World Bank, 2007. Doing Business 2008. World Bank Publications, Washington DC.

Zingales, Luigi (2004), “The Costs and Benefits of Financial Market Regulation,” April, ECGI Law Working Paper 21/2004. Available at http://ssrn.com/abstract=536682 (visited October 4, 2007). 


\section{Annex}

Figure 1. Parallel evolution of account publication at the Spanish Company Register and turnover of the top three credit information agencies, 1997-2005

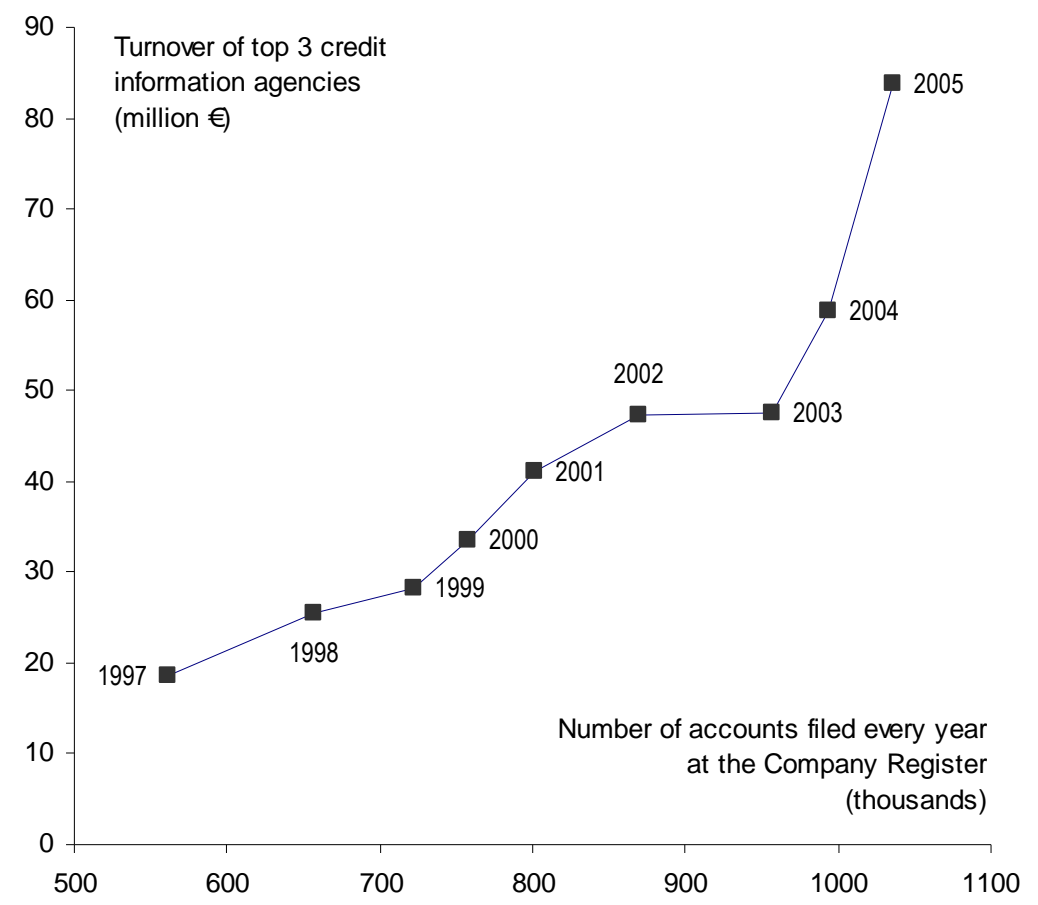

Source: Built with data from DGRN (several years), for the number of accounts, and the SABI database, provided by Bureau va Dijk, for turnover. Firms included are Informa D\&B S.A., Iberinform Internacional S.A. and Infotel Información y Telecomunicaciones S.A. Equifax Ibérica S.L. is excluded because its turnover data is distorted by extraneous factors. 
Table 1. Survey questions and responses by customers of the online credit information service

\begin{tabular}{|c|c|c|c|c|c|c|}
\hline & \multirow{2}{*}{ All } & \multirow{2}{*}{$\%$} & \multicolumn{4}{|c|}{ Usually consult information about: } \\
\hline & & & \multicolumn{2}{|c|}{ Large firms } & \multicolumn{2}{|c|}{ Small firms } \\
\hline \multicolumn{7}{|l|}{ 1. You usually consult this information to: } \\
\hline $\begin{array}{l}\text { Get information on large firms (those with, approximately, more than } 50 \\
\text { workers, } 4.4 \text { million Euros of assets and/or } 8.8 \text { millions of turnover) }\end{array}$ & 665 & $11.23 \%$ & & & & \\
\hline Get information on small and medium-sized firms (all other) & 5,259 & $88.77 \%$ & & & & \\
\hline No answer & 0 & $0.00 \%$ & & & & \\
\hline \multicolumn{7}{|c|}{ 2. What advantages does your firm get from having access to this information? (Mark one or several responses): } \\
\hline Carry out sales that otherwise would not do & 2,723 & $45.97 \%$ & 332 & $49.92 \%$ & 2,391 & $45.46 \%$ \\
\hline Grant credit to new clients & 3,579 & $60.42 \%$ & 349 & $52.48 \%$ & 3,230 & $61.42 \%$ \\
\hline Grant more credit to old clients & 1,174 & $19.82 \%$ & 137 & $20.60 \%$ & 1,037 & $19.72 \%$ \\
\hline Sell in regions where we had not sold before & 848 & $14.31 \%$ & 106 & $15.94 \%$ & 742 & $14.11 \%$ \\
\hline No answer & 175 & $2.95 \%$ & 21 & $3.16 \%$ & 154 & $2.93 \%$ \\
\hline \multicolumn{7}{|c|}{ 3. What information do you value most about a firm? (Mark one or several responses): } \\
\hline Accounts (balance sheet, profit and loss accounts) & 4,958 & $83.69 \%$ & 566 & $85.11 \%$ & 4,392 & $83.51 \%$ \\
\hline Judicial incidents & 3,255 & $54.95 \%$ & 305 & $45.86 \%$ & 2,950 & $56.09 \%$ \\
\hline Corporate information (board, site, legal address, register data) & 1,857 & $31.35 \%$ & 223 & $33.53 \%$ & 1,634 & $31.07 \%$ \\
\hline Contact data & 1,035 & $17.47 \%$ & 114 & $17.14 \%$ & 921 & $17.51 \%$ \\
\hline Other & 478 & $8.07 \%$ & 46 & $6.92 \%$ & 432 & $8.21 \%$ \\
\hline No answer & 19 & $0.32 \%$ & 2 & $0.30 \%$ & 17 & $0.32 \%$ \\
\hline \multicolumn{7}{|c|}{ 4. How do you interpret the fact that a company on which you are inquiring has not filed its accounts at the Company Register? } \\
\hline The firm is unreliable and its default risk is greater & 3,402 & $57.43 \%$ & 388 & $58.35 \%$ & 3,014 & $57.31 \%$ \\
\hline $\begin{array}{l}\text { I do not conclude anything because there are many reasons for not } \\
\text { publishing the accounts. I try to get additional information. }\end{array}$ & 2,463 & $41.58 \%$ & 269 & $40.45 \%$ & 2,194 & $41.72 \%$ \\
\hline No answer & 59 & $1.00 \%$ & 8 & $1.20 \%$ & 51 & $0.97 \%$ \\
\hline \multicolumn{7}{|c|}{ 5. You use our services to get information on... (mark one or several responses): } \\
\hline Suppliers & 1,513 & $25.54 \%$ & 205 & $30.83 \%$ & 1,308 & $24.87 \%$ \\
\hline Clients & 5,092 & $85.96 \%$ & 558 & $83.91 \%$ & 4,534 & $86.21 \%$ \\
\hline Competitors & 2,501 & $42.22 \%$ & 309 & $46.47 \%$ & 2,192 & $41.68 \%$ \\
\hline Other & 595 & $10.04 \%$ & 50 & $7.52 \%$ & 545 & $10.36 \%$ \\
\hline No answer & 35 & $0.59 \%$ & 5 & $0.75 \%$ & 30 & $0.57 \%$ \\
\hline \multicolumn{7}{|l|}{ 6. You use our services to decide about... (mark one or several responses): } \\
\hline Purchases and supplies & 927 & $15.65 \%$ & 133 & $20.00 \%$ & 794 & $15.10 \%$ \\
\hline Sales on credit & 3,966 & $66.95 \%$ & 416 & $62.56 \%$ & 3.550 & $67.50 \%$ \\
\hline Marketing research & 1,622 & $27.38 \%$ & 214 & $32.18 \%$ & 1.408 & $26.77 \%$ \\
\hline Studies and analysis & 2,112 & $35.65 \%$ & 273 & $41.05 \%$ & 1.839 & $34.97 \%$ \\
\hline Other & 633 & $10.69 \%$ & 56 & $8.42 \%$ & 577 & $10.97 \%$ \\
\hline No answer & 59 & $1.00 \%$ & 8 & $1.20 \%$ & 51 & $0.97 \%$ \\
\hline \multicolumn{7}{|l|}{ 7. How do you use our services? (Mark one or several responses): } \\
\hline For new relationships of special significance & 2,843 & $47.99 \%$ & 341 & $51.28 \%$ & 2,502 & $47.58 \%$ \\
\hline For all new commercial relationships & 2,193 & $37.02 \%$ & 237 & $35.64 \%$ & 1,956 & $37.19 \%$ \\
\hline To monitor old relationships of special significance & 1,772 & $29.91 \%$ & 229 & $34.44 \%$ & 1,543 & $29.34 \%$ \\
\hline To monitor old relationships & 1,121 & $18.92 \%$ & 111 & $16.69 \%$ & 1,010 & $19.21 \%$ \\
\hline Other & 957 & $16.15 \%$ & 111 & $16.69 \%$ & 846 & $16.09 \%$ \\
\hline No answer & 77 & $1.30 \%$ & 7 & $1.05 \%$ & 70 & $1.33 \%$ \\
\hline \multicolumn{7}{|c|}{ 8. Which other methods do you use to gather information on solvency of clients and other commercial partners? } \\
\hline Their history of payments with our firm & 3,152 & $53.21 \%$ & 355 & $53.38 \%$ & 2,797 & $53.19 \%$ \\
\hline Information provided by my bank & 2,794 & $47.16 \%$ & 297 & $44.66 \%$ & 2,497 & $47.48 \%$ \\
\hline References of other firms & 2,478 & $41.83 \%$ & 252 & $37.89 \%$ & 2,226 & $42.33 \%$ \\
\hline Other & 1,175 & $19.83 \%$ & 138 & $20.75 \%$ & 1,037 & $19.72 \%$ \\
\hline No answer & 64 & $1.08 \%$ & 10 & $1.50 \%$ & 54 & $1.03 \%$ \\
\hline
\end{tabular}


Table 2. Descriptive statistics of variables used in the econometric analysis

\begin{tabular}{|c|c|c|c|c|c|c|c|c|c|c|c|c|c|c|c|c|c|c|c|c|}
\hline \multirow{2}{*}{ Variables } & \multicolumn{5}{|c|}{ All firms } & \multicolumn{5}{|c|}{ Micro firms } & \multicolumn{5}{|c|}{ Small firms } & \multicolumn{5}{|c|}{ Large firms } \\
\hline & Obs & Mean & Std. Dev. & Min & Max & Obs & Mean & Std. Dev. & Min & Max & Obs & Mean & Std. Dev. & Min & Max & Obs & Mean & Std. Dev. & Min & Max \\
\hline \multicolumn{21}{|l|}{$\begin{array}{l}\text { Data obtained from the } \\
\text { database: }\end{array}$} \\
\hline Workers & 5593 & 38.08 & 377.63 & 1.00 & $23,229.00$ & 1583 & 25.41 & 87.83 & 1.00 & $1,656.00$ & 3087 & 38.64 & 272.04 & 1.00 & 10,000 & 549 & 72.00 & 995.27 & 1.00 & 23,229 \\
\hline Assets & 4565 & 4,006 & 17,500 & 1 & 428,000 & 1269 & 2,997 & 11,500 & 1 & 264,000 & 2542 & 4,081 & 16,000 & 1 & 364,000 & 463 & 4,759 & 20,100 & 5 & 324,000 \\
\hline Turnover & 4509 & 4,633 & 21,100 & 0 & 641,000 & 1259 & 3,317 & 9,355 & 0 & 190,000 & 2509 & 4,838 & 19,700 & 0 & 587,000 & 457 & 5,695 & 29,500 & 7 & 597,000 \\
\hline Log of Workers & 5593 & 2.25 & 1.36 & 0.00 & 10.05 & 1583 & 2.16 & 1.30 & 0.00 & 7.41 & 3087 & 2.28 & 1.37 & 0.00 & 9.21 & 549 & 2.38 & 1.36 & 0.00 & 10.05 \\
\hline Log of Assets & 4565 & 13.75 & 1.66 & 6.27 & 19.87 & 1269 & 13.61 & 1.62 & 6.86 & 19.39 & 2542 & 13.82 & 1.64 & 6.27 & 19.71 & 463 & 13.89 & 1.66 & 8.42 & 19.60 \\
\hline Log of Turnover & 4509 & 14.03 & 1.61 & 4.90 & 20.28 & 1259 & 13.89 & 1.56 & 4.90 & 19.06 & 2509 & 14.09 & 1.62 & 6.14 & 20.19 & 457 & 14.15 & 1.59 & 8.88 & 20.21 \\
\hline Firm Size Index ${ }^{a}$ & 4507 & 0.00 & 1.56 & -5.97 & 7.13 & 1259 & -0.14 & 1.49 & -5.36 & 5.54 & 2508 & 0.06 & 1.58 & -5.97 & 7.13 & 456 & 0.14 & 1.56 & -4.43 & 5.84 \\
\hline Cross Border Index & 5866 & 0.57 & 1.04 & 0.00 & 3.00 & 1671 & 0.50 & 0.98 & 0.00 & 3.00 & 3217 & 0.61 & 1.07 & 0.00 & 3.00 & 570 & 0.72 & 1.14 & 0.00 & 3.00 \\
\hline Log of Firm Age & 5856 & 4.92 & 0.71 & 1.79 & 7.22 & 1669 & 4.85 & 0.72 & 2.40 & 7.17 & 3212 & 4.95 & 0.70 & 1.79 & 7.14 & 567 & 5.02 & 0.70 & 2.40 & 7.08 \\
\hline \multicolumn{21}{|l|}{$\begin{array}{l}\text { Data obtained from } \\
\text { the survey: }\end{array}$} \\
\hline Sales & 5924 & 0.58 & 0.49 & 0.00 & 1.00 & 1691 & 0.59 & 0.49 & 0.00 & 1.00 & 3245 & 0.57 & 0.50 & 0.00 & 1.00 & 572 & 0.57 & 0.50 & 0.00 & 1.00 \\
\hline Marketing & 5924 & 0.17 & 0.37 & 0.00 & 1.00 & 1691 & 0.17 & 0.38 & 0.00 & 1.00 & 3245 & 0.16 & 0.37 & 0.00 & 1.00 & 572 & 0.17 & 0.38 & 0.00 & 1.00 \\
\hline Finance & 5924 & 0.60 & 0.49 & 0.00 & 1.00 & 1691 & 0.59 & 0.49 & 0.00 & 1.00 & 3245 & 0.61 & 0.49 & 0.00 & 1.00 & 572 & 0.59 & 0.49 & 0.00 & 1.00 \\
\hline Competitors & 5924 & 0.42 & 0.49 & 0.00 & 1.00 & 1691 & 0.40 & 0.49 & 0.00 & 1.00 & 3245 & 0.43 & 0.50 & 0.00 & 1.00 & 572 & 0.42 & 0.49 & 0.00 & 1.00 \\
\hline Large firms & 5924 & 0.11 & 0.32 & 0.00 & 1.00 & 1691 & 0.10 & 0.30 & 0.00 & 1.00 & 3245 & 0.12 & 0.32 & 0.00 & 1.00 & 572 & 0.10 & 0.30 & 0.00 & 1.00 \\
\hline Grant credit to new clients & 5924 & 0.60 & 0.49 & 0.00 & 1.00 & 1691 & 0.60 & 0.49 & 0.00 & 1.00 & 3245 & 0.61 & 0.49 & 0.00 & 1.00 & 572 & 0.62 & 0.49 & 0.00 & 1.00 \\
\hline Extend credit to old clients & 5924 & 0.20 & 0.40 & 0.00 & 1.00 & 1691 & 0.18 & 0.39 & 0.00 & 1.00 & 3245 & 0.20 & 0.40 & 0.00 & 1.00 & 572 & 0.20 & 0.40 & 0.00 & 1.00 \\
\hline Sell in newregions & 5924 & 0.14 & 0.35 & 0.00 & 1.00 & 1691 & 0.15 & 0.35 & 0.00 & 1.00 & 3245 & 0.13 & 0.34 & 0.00 & 1.00 & 572 & 0.15 & 0.36 & 0.00 & 1.00 \\
\hline
\end{tabular}

Notes: The Frm Size index is built as a principal component of the number of workers and the amount of assets and turnover in 2005. 
Table 3. Econometric analysis

\begin{tabular}{|c|c|c|c|c|c|}
\hline & \multicolumn{5}{|c|}{ Dependent variables (estimated equations in columns) } \\
\hline & \multicolumn{2}{|c|}{$\begin{array}{l}\text { The user consults the service to obtain } \\
\text { information on: }\end{array}$} & \multicolumn{3}{|c|}{$\begin{array}{l}\text { Advantages that the user firm obtains } \\
\text { from having access to the information: }\end{array}$} \\
\hline & $\begin{array}{l}\text { Competitors } \\
\text { Q5.A3 } \\
\text { (1) }\end{array}$ & $\begin{array}{l}\text { Large firms } \\
\text { (usually) } \\
\text { Q1.A1 } \\
(2)\end{array}$ & $\begin{array}{l}\text { Grant credit to } \\
\text { new clients } \\
\text { Q2.A2 } \\
\text { (3) }\end{array}$ & $\begin{array}{l}\text { Extend credit to } \\
\text { old clients } \\
\text { Q2.A2 } \\
\text { (4) }\end{array}$ & $\begin{array}{l}\text { Sell in new } \\
\text { regions } \\
\text { Q2.A2 } \\
\text { (5) }\end{array}$ \\
\hline Firm Size index & $\begin{array}{l}0.087^{* * *} \\
(0.014)\end{array}$ & $\begin{array}{l}0.217^{* * *} \\
(0.019)\end{array}$ & $\begin{array}{l}0.043^{* * *} \\
(0.014)\end{array}$ & $\begin{array}{l}0.023 \\
(0.016)\end{array}$ & $\begin{array}{l}-0.015 \\
(0.018)\end{array}$ \\
\hline Cross Border Index & $\begin{array}{l}0.041^{* *} \\
(0.019)\end{array}$ & $\begin{array}{l}0.014 \\
(0.024)\end{array}$ & $\begin{array}{l}0.072^{* * *} \\
(0.019)\end{array}$ & $\begin{array}{l}0.081^{* * *} \\
(0.020)\end{array}$ & $\begin{array}{l}0.109^{* * *} \\
(0.023)\end{array}$ \\
\hline Log of Firm Age & $\begin{array}{l}-0.023 \\
(0.035)\end{array}$ & $\begin{array}{l}-0.121^{* * *} \\
(0.045)\end{array}$ & $\begin{array}{l}0.094^{* * *} \\
(0.035)\end{array}$ & $\begin{array}{l}0.030 \\
(0.039)\end{array}$ & $\begin{array}{l}-0.072^{*} \\
(0.044)\end{array}$ \\
\hline Sales & $\begin{array}{l}0.089^{*} \\
(0.046)\end{array}$ & $\begin{array}{l}-0.191^{* * *} \\
(0.062)\end{array}$ & $\begin{array}{l}0.237^{* * *} \\
(0.047)\end{array}$ & $\begin{array}{l}0.161^{* * *} \\
(0.052)\end{array}$ & $\begin{array}{l}0.092 \\
(0.057)\end{array}$ \\
\hline Marketing & $\begin{array}{l}0.468^{* * *} \\
(0.054)\end{array}$ & $\begin{array}{l}0.180^{* * *} \\
(0.069)\end{array}$ & $\begin{array}{l}-0.177^{\star * *} \\
(0.054)\end{array}$ & $\begin{array}{l}-0.026 \\
(0.061)\end{array}$ & $\begin{array}{l}0.322^{* * *} \\
(0.062)\end{array}$ \\
\hline Finance & $\begin{array}{l}0.207^{* * *} \\
(0.046)\end{array}$ & $\begin{array}{l}-0.190^{* * *} \\
(0.061)\end{array}$ & $\begin{array}{l}0.288^{* * *} \\
(0.047)\end{array}$ & $\begin{array}{l}0.313^{* * *} \\
(0.053)\end{array}$ & $\begin{array}{l}-0.027 \\
(0.056)\end{array}$ \\
\hline Constant & $\begin{array}{l}-0.309^{*} \\
(0.181)\end{array}$ & $\begin{array}{l}-0.448^{*} \\
(0.233)\end{array}$ & $\begin{array}{l}-0.465^{\star *} \\
(0.183)\end{array}$ & $\begin{array}{l}-1.333^{* * *} \\
(0.205)\end{array}$ & $\begin{array}{l}-0.912^{\star * *} \\
(0.225)\end{array}$ \\
\hline Observations & 4506 & 4506 & 4506 & 4506 & 4506 \\
\hline Pseudo R-squared & 0.0278 & 0.0575 & 0.0190 & 0.0152 & 0.0179 \\
\hline
\end{tabular}

Probit regressions. Standard errors in parentheses. " significant at 10\%; "* significant at 5\%; ;" significant at 1\%. (Qx.Ay): numbers of corresponding questions and answers in the survey. 
Table 4. Number of company accounts requested from three Spanish Company Registers in the last week of September 2007, classified by company size

\begin{tabular}{|c|c|c|c|c|c|c|c|}
\hline & \multicolumn{4}{|c|}{ Potentially exempted companies } & \multirow{2}{*}{\multicolumn{2}{|c|}{$\begin{array}{c}\text { Medium and large } \\
\text { companies that could not be } \\
\text { exempted by national law }\end{array}$}} & \multirow{3}{*}{$\begin{array}{c}\text { Total } \\
\text { number of } \\
\text { companies }\end{array}$} \\
\hline & \multicolumn{2}{|c|}{ Micro entities } & \multicolumn{2}{|c|}{ Small companies } & & & \\
\hline & Thresholds & Number & Thresholds & Number & Thresholds & Number & \\
\hline $\begin{array}{l}\text { Number of } \\
\text { employees, } N\end{array}$ & $N<10$ & 446 & $10 \leq N<50$ & 164 & $N \geq 50$ & 24 & 634 \\
\hline Total assets, $A$ & $A<0.5 \mathrm{~m} €$ & 319 & $\begin{array}{l}0.5 \mathrm{~m} € \leq A \\
<4.4 \mathrm{~m} €\end{array}$ & 253 & $A \geq 4.4 \mathrm{~m} €$ & 62 & 634 \\
\hline Turnover, $T$ & $T<1 \mathrm{~m} €$ & 405 & $\begin{array}{l}1 \mathrm{~m} € \leq T \\
<8.8 \mathrm{~m} €\end{array}$ & 202 & $T \geq 8.8 \mathrm{~m} €$ & 27 & 634 \\
\hline $\begin{array}{l}\text { Estimated } \\
\text { number of } \\
\text { companies } \\
\text { in each size } \\
\text { group: }\end{array}$ & $\begin{array}{l}\text { Meeting } \\
\text { all three } \\
\text { thresholds to be } \\
\text { a micro entity }\end{array}$ & 272 & $\begin{array}{l}\text { Meeting at least } \\
\text { two of the three } \\
\text { criteria to be } \\
\text { small, or two of } \\
\text { the three upper } \\
\text { bounds to be } \\
\text { small and not } \\
\text { meeting at least } \\
\text { one required to } \\
\text { be a micro entity }\end{array}$ & 333 & $\begin{array}{l}\text { Not meeting the } \\
\text { three upper } \\
\text { bounds to be } \\
\text { small, or } \\
\text { meeting only } \\
\text { one of the upper } \\
\text { bounds to be } \\
\text { small }\end{array}$ & 29 & 634 \\
\hline $\begin{array}{l}\text { Percentage of } \\
\text { total companies }\end{array}$ & & $42.90 \%$ & & $52.52 \%$ & & $4.57 \%$ & $100.00 \%$ \\
\hline
\end{tabular}

Source: Company registers of Ciudad Real, Palma de Mallorca and Valladolid. Accounts requested from the 24th to the 28th of September, 2007. 
Table 5. Estimation of the number of Spanish companies whose accounts have been reported by the Spanish Commercial Register to Informa D\&B S.A. and which would be affected by the exemption proposed by the European Commission, indicating the proportion in each size group that do cross-border trade

\begin{tabular}{|c|c|c|c|c|c|c|c|}
\hline & \multicolumn{4}{|c|}{ Potentially exempted companies } & \multirow{2}{*}{\multicolumn{2}{|c|}{$\begin{array}{c}\text { Medium and large } \\
\text { companies that not exempted } \\
\text { by national law }\end{array}$}} & \multirow{3}{*}{$\begin{array}{c}\text { Total } \\
\text { number of } \\
\text { companies }\end{array}$} \\
\hline & \multicolumn{2}{|c|}{ Micro entities } & \multicolumn{2}{|c|}{ Small companies } & & & \\
\hline & Bounds & Number & Bounds & Number & Bounds & Number & \\
\hline $\begin{array}{l}\text { Number of } \\
\text { employees, } N\end{array}$ & $N<10$ & 328,871 & $10 \leq N<50$ & 112,693 & $N \geq 50$ & 19,120 & 460,684 \\
\hline Total assets, $A$ & $A<0.5 \mathrm{~m} €$ & 352,275 & $\begin{array}{c}0.5 \mathrm{~m} € \leq A \\
<4.4 \mathrm{~m} €\end{array}$ & 207,013 & $A \geq 4.4 \mathrm{~m} €$ & 50,672 & 609,960 \\
\hline \multirow[t]{3}{*}{ Turnover, $T$} & $T<1 \mathrm{~m} €$ & 442,181 & $\begin{array}{l}1 \mathrm{~m} € \leq T \\
<8.8 \mathrm{~m} €\end{array}$ & 132,722 & $T \geq 8.8 \mathrm{~m} €$ & 19,896 & 594,799 \\
\hline & $\begin{array}{l}\text { Meeting the } \\
\text { three bounds } \\
\text { to be a micro } \\
\text { entity }\end{array}$ & 222,422 & $\begin{array}{l}\text { Meeting at least } \\
\text { two of the three } \\
\text { criteria to be } \\
\text { small }\end{array}$ & 115,039 & $\begin{array}{l}\text { Not meeting the } \\
\text { three upper } \\
\text { bounds to be } \\
\text { small }\end{array}$ & 10,189 & \\
\hline & & & $\begin{array}{l}\text { Meeting at least } \\
\text { two of the three } \\
\text { upper bounds to } \\
\text { be small and not } \\
\text { meeting at least } \\
\text { one required to } \\
\text { be a micro entity }\end{array}$ & 100,263 & $\begin{array}{l}\text { Meeting only } \\
\text { one of the upper } \\
\text { bounds to be } \\
\text { small }\end{array}$ & 7,791 & \\
\hline $\begin{array}{l}\text { Estimated number } \\
\text { of companies in } \\
\text { each size group }\end{array}$ & & 222,422 & & 215,302 & & $17,980^{b}$ & 455,704 \\
\hline $\begin{array}{l}\text { Percentage of } \\
\text { total companies }\end{array}$ & & $48.81 \%$ & & $47.25 \%$ & & 3. $95 \%$ & $100.00 \%$ \\
\hline $\begin{array}{l}\text { Number of } \\
\text { companies doing } \\
\text { cross-border trade } \\
\text { in each size group }\end{array}$ & & 10,338 & & 35,081 & & 9,024 & 54,443 \\
\hline $\begin{array}{l}\text { Percentage of } \\
\text { companies with } \\
\text { cross- border trade } \\
\text { in each group }\end{array}$ & & $4.65 \%$ & & $16.29 \%$ & & $50.19 \%$ & $11.95 \%$ \\
\hline
\end{tabular}

Source: SABI online database, provided by Bureau va Dijk with data from Informa D\&B S.A., on the limited liability companies with full data for financial year 2005. Note: a Availability of data differs between categories mainly because the number of employees is missing for a substantial number of observations, given that reporting on this number is not mandatory. As a consequence of this missing data, the number of micro-entities is likely to be underestimated. For instance, if instead of using the number of employees, we had used a salaries threshold, the number of micro entities would have been 305,582 considering micro entities to be companies that in 2005 paid less than $300,000 €$ in salaries, and 289,001 considering companies that paid less than $200,000 €$ in salaries. ${ }^{b}$ In addition, 12,862 of these companies could be exempted because they are medium-sized and "have no particular external user" (European Commission, 2007: 17). 